\title{
A New Perspective on the Geometry of the San Andreas Fault in Southern California and Its Relationship to Lithospheric Structure
}

\author{
by Gary S. Fuis, Daniel S. Scheirer, Victoria E. Langenheim, and Monica D. Kohler*
}

\begin{abstract}
The widely held perception that the San Andreas fault (SAF) is vertical or steeply dipping in most places in southern California may not be correct. From studies of potential-field data, active-source imaging, and seismicity, the dip of the SAF is significantly nonvertical in many locations. The direction of dip appears to change in a systematic way through the Transverse Ranges: moderately southwest $\left(55^{\circ}-75^{\circ}\right)$ in the western bend of the SAF in the Transverse Ranges (Big Bend); vertical to steep in the Mojave Desert; and moderately northeast $\left(37^{\circ}-65^{\circ}\right)$ in a region extending from San Bernardino to the Salton Sea, spanning the eastern bend of the SAF in the Transverse Ranges. The shape of the modeled SAF is crudely that of a propeller. If confirmed by further studies, the geometry of the modeled SAF would have important implications for tectonics and strong ground motions from SAF earthquakes. The SAF can be traced or projected through the crust to the north side of a well documented high-velocity body (HVB) in the upper mantle beneath the Transverse Ranges. The north side of this HVB may be an extension of the plate boundary into the mantle, and the HVB would appear to be part of the Pacific plate.
\end{abstract}

\section{Introduction}

In the Southern California Earthquake Center Community Fault Model (CFM; Plesch et al., 2007), the dip of the San Andreas fault (SAF) is $90^{\circ}$ in all but one location, as there is little subsurface data to modify this default value. The one exception is the San Gorgonio Pass SGP area of the eastern Transverse Ranges (Fig. 1), where surface constraints and seismicity have been used to justify a nonvertical dip in the model. In this study, we constrain the dip of the SAF by analyzing near-surface and subsurface data, including potential field, seismic-imaging, and seismicity observations, from a number of locations in southern California. Surprisingly, the SAF is significantly nonvertical in most places, dipping away from the bends at either end of its stretch through the Transverse Ranges, where it is oblique to plate motion. The overall shape of the SAF is similar to that of a propeller. The fault appears to extend or project through the crust to join the north side of the well known upper-mantle high-velocity body (HVB) beneath the Transverse Ranges that has been imaged with teleseismic tomography and Rayleigh waves. These findings, if confirmed in further studies, would have important implications for understanding the tectonics and strong- ground-motion potential from SAF earthquakes, such

\footnotetext{
*Now at Department of Mechanical and Civil Engineering, California Institute of Technology, Pasadena, California 91125.
}

as the scenario $M 7.8$ earthquake of ShakeOut (Perry et al., 2008).

\section{Tectonic Setting}

Through the Transverse Ranges, the SAF strikes obliquely to relative plate motion with bends at either end of the oblique stretch (Fig. 1). The Los Angeles Region Seismic Experiment (LARSE) transects (Fig. 1, profiles 4 and 5), which were recorded across this oblique section of the SAF, reveal interpreted fluid-lubricated midcrustal decollements originating at the SAF and extending southward into the Pacific plate. Reverse faults that splay upward from these decollements have given rise to destructive earthquakes in the Los Angeles region, including the $1971 M_{\mathrm{w}} 6.7$ San Fernando and $1987 M_{\mathrm{w}} 5.9$ Whittier Narrows earthquakes (Fuis et al., 2001, 2003). A crustal root is observed beneath the Transverse Ranges centered, or nearly centered, on the SAF (Kohler and Davis, 1997; Fuis et al., 2001; Godfrey et al., 2002; Fuis et al., 2007). The tectonic interpretation of this crustal structure is that the upper crust, above the decollements, responds to convergence in this oblique section of the SAF by vertical and lateral motion, whereas the lower crust is compressed into the crustal root (Houseman et al., 


\section{홍
言
口.}
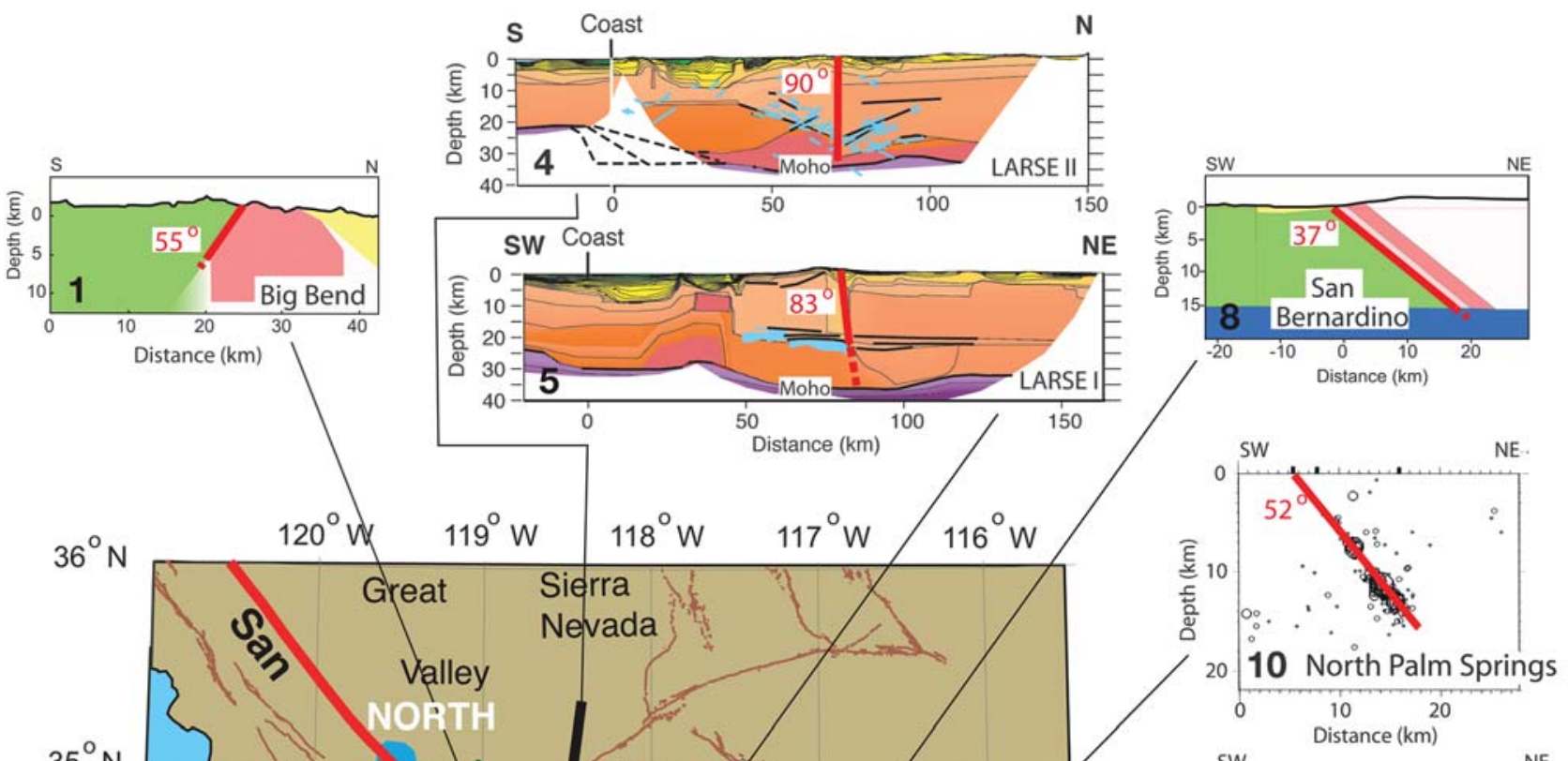

$$
35^{\circ} \mathrm{N}
$$
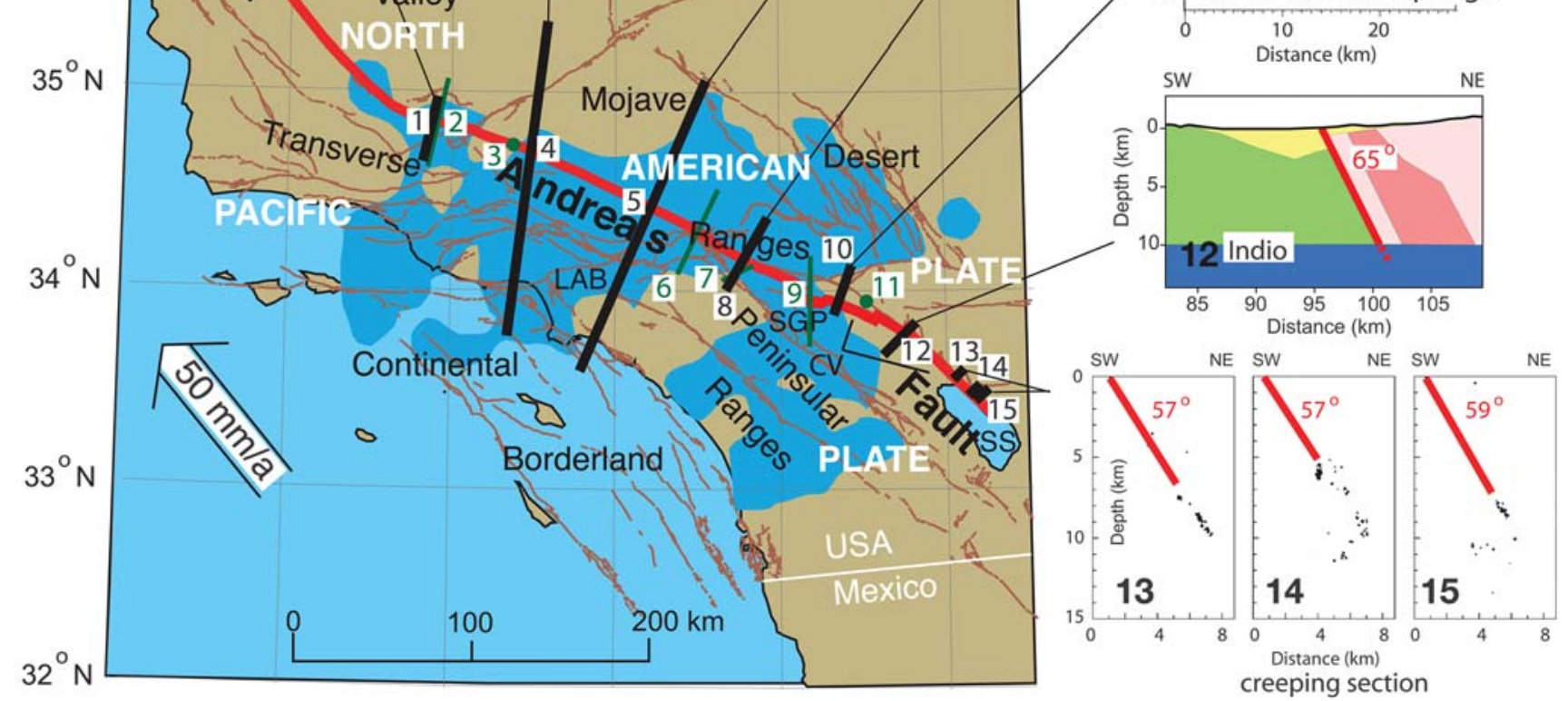

Figure 1. Fault map of southern California and cross sections showing dipping San Andreas fault (SAF). Black and green lines, profiles discussed in paper; green dots, additional locations discussed. Profiles and locations are numbered sequentially from northwest to southeast, 1-15. Cross sections along black lines $(1,4,5,8,10,12,13,14$, and 15) are shown as satellite diagrams with geographic location labels. Cross section 10 is reproduced with interpreted SAF (red line) from Jones et al. (1986; their fig. 3a). Cross sections 13-15 are reproduced with interpreted SAF (red lines) from Lin et al. (2007; their fig. 14). Green lines 2, 6, and 9 are locations of seismicity cross sections of Figure 9. Green line 7 is location of seismic-imaging profile through San Bernardino Valley (see text). Green dots 3 and 11 are locations, Three Points and Desert Hot Springs (see text). Heavy red line, San Andreas fault; reddish brown lines, other active faults (Jennings, 1994). Blue body, horizontal slice through upper-mantle high-velocity body at 110-km depth (see Kohler et al., 2003, their fig. 7A). Colors in cross sections 1 , 8, and 12 are explained in Figure 3. Colors and symbols in cross sections 4 and 5 are explained in Figure 10. Abbreviations: CV, Coachella Valley; LAB, Los Angeles basin; SGP, San Gorgonio Pass; SS, Salton Sea.

2000; Fuis et al., 2001; Godfrey et al., 2002; Fuis et al., 2007).

\section{Data Constraining Fault Dip}

At a number of locations in southern California, we estimate the dip of the SAF from analysis of potential field, seismicity, and seismic-imaging observations (Fig. 1). Where possible, we assign an uncertainty to the dip values. Except for the LARSE observations that constrain the geometry throughout the crust, geophysical observations generally constrain the SAF geometry in only the upper 5-15 km of the crust. For simplicity, we assume a constant dip as a function of depth for the SAF at the location of every constraint along its trace, except in the San Gorgonio Pass area where shallower indicators suggest a very gentle dip but deeper indicators suggest a steeper dip. In addition, we linearly interpolate these dip values along the SAF trace between the constraint locations (Fig. 2), with interpolation distances that range from about 15 to $120 \mathrm{~km}$. Because of the 
(a)

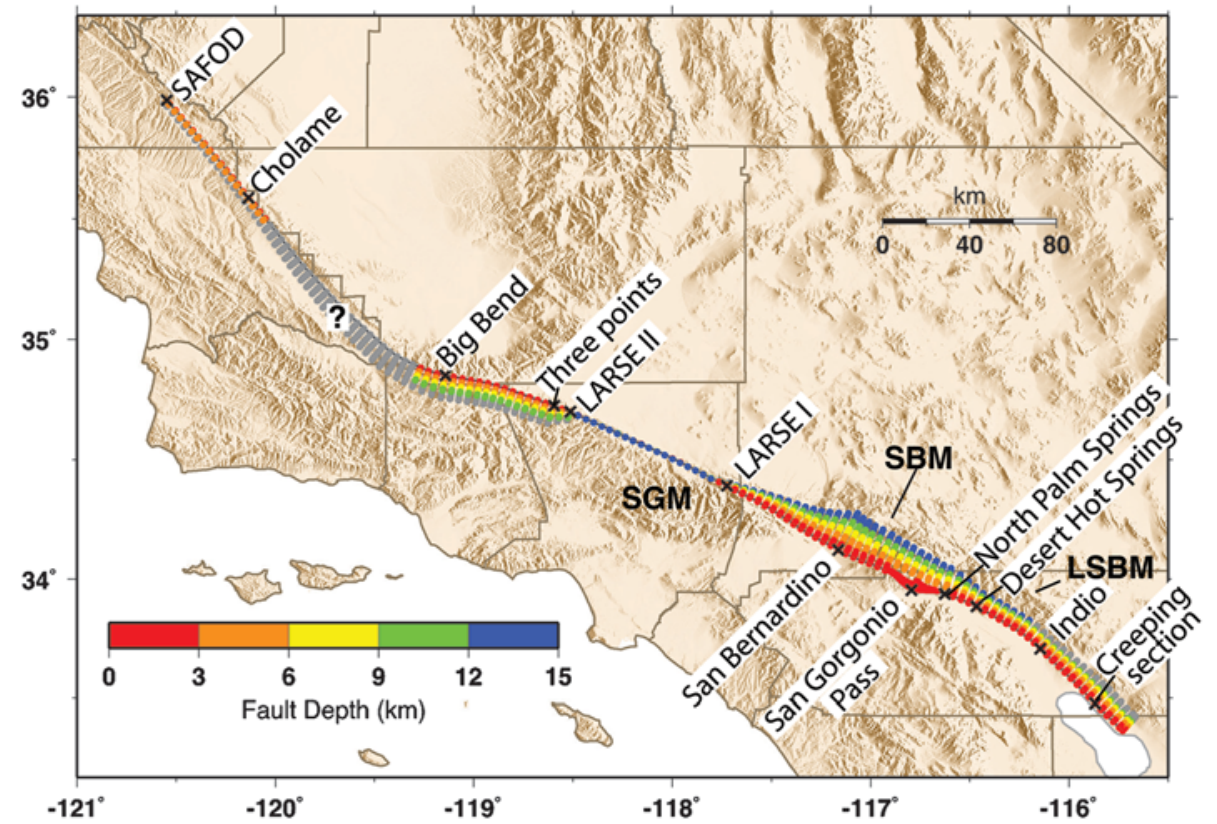

(b)

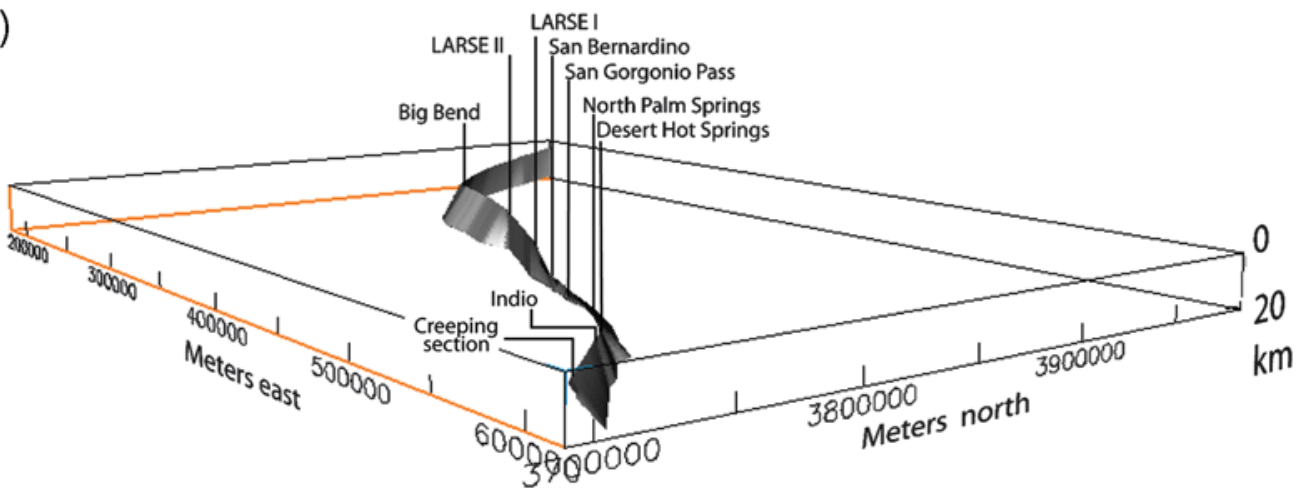

Figure 2. (a) Plan view of dipping SAF model surface colored by depth; gray colors, unconstrained projections. Mountain ranges within Transverse Ranges (see Fig. 1): SGM, San Gabriel Mountains; SBM, San Bernardino Mountains; LSBM, Little San Bernardino Mountains; SAFOD, San Andreas Fault Observatory at Depth. (b) Oblique view of SAF surface from southeast.

heterogeneous nature of our constraining observations and because of the simplifications and interpolations required to generate this dipping SAF model, we view the strength of this model to be simply its depiction of systematic and significant dip variations along the SAF.

\section{Potential Field}

A published model of gravity data across the SAF in the vicinity of the Big Bend in the western Transverse Ranges (Griscom and Jachens, 1990) indicates a southwestward dip as shallow as $55^{\circ}$ (Fig. 1, profile 1; Fig. 3a). The SAF is modeled to a depth as great as $5 \mathrm{~km}$. At 120-180 km northwest of this model location (at Cholame and the San Andreas Fault Observatory at Depth [SAFOD]); Fig. 2a], a steeper southwest dip is seen in the upper few kilometers of the crust, $70^{\circ}-90^{\circ}$ from gravity data at Cholame (Griscom and Jachens, 1990 ) and $83^{\circ}$ from drilling observations at SAFOD (Zoback et al., 2010). About $50 \mathrm{~km}$ southeast of the Big Bend cross section (at Three Points; Fig. 1; Fig. 2a), gravity and magnetic data also suggest a southwestward dip $\left(30^{\circ}-75^{\circ}\right)$, but uncertainty is greater. In the San Gorgonio Pass area, approximately $250 \mathrm{~km}$ southeast of the Big Bend cross section, gravity modeling indicates that the Banning strand of the SAF dips very gently $\left(10^{\circ}-15^{\circ}\right)$ to the northeast in the upper few kilometers (Griscom and Jachens, 1990; Langenheim et al., 2005) (Fig. 2a). In this study we model two additional profiles of magnetic data, at San Bernardino and at Indio (Fig. 1, profiles 8 and 12), that indicate dips of $37^{\circ}$ and $65^{\circ}$, respectively (Fig. $3 b, c$ ).

A nearly continuous magnetic anomaly extends along the SAF from the northwestern San Bernardino Mountains to Indio, averaging 200-500 nT at a nominal height of $300 \mathrm{~m}$ above terrain (Fig. 4; Griscom and Jachens, 1990). This magnetic anomaly is predominantly positive and is spatially associated with outcrop of units labeled as Precambrian igneous and metamorphic rock complex in the portions of 
(a)

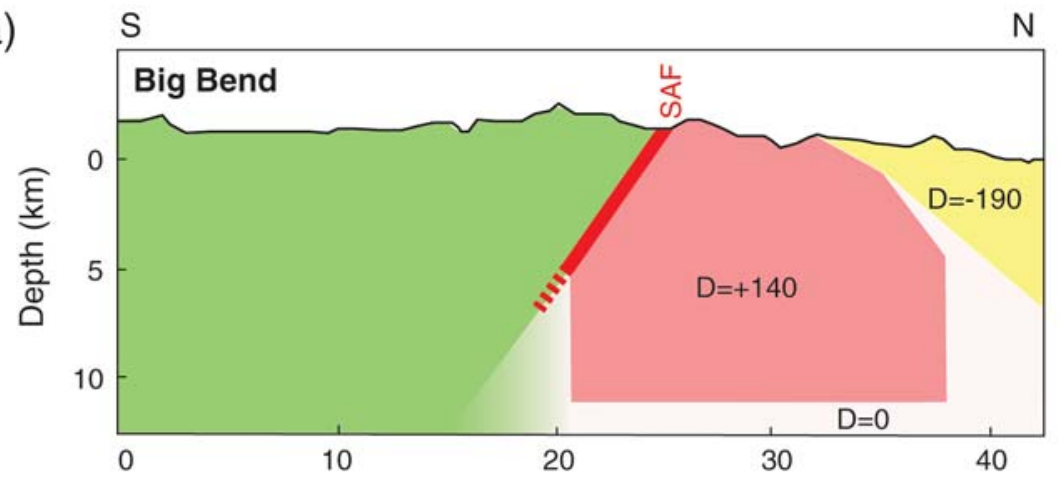

(b)

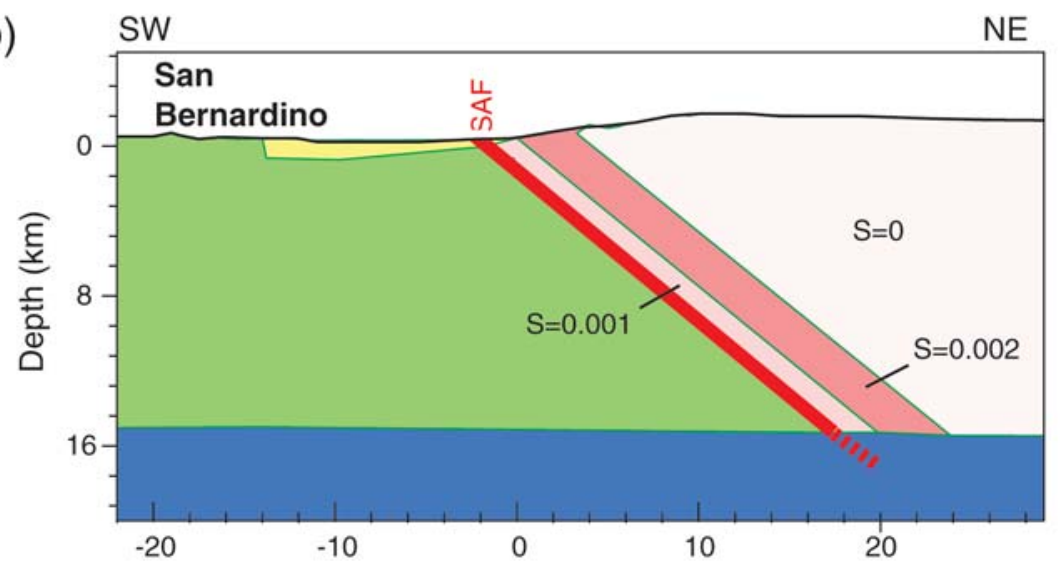

(c)
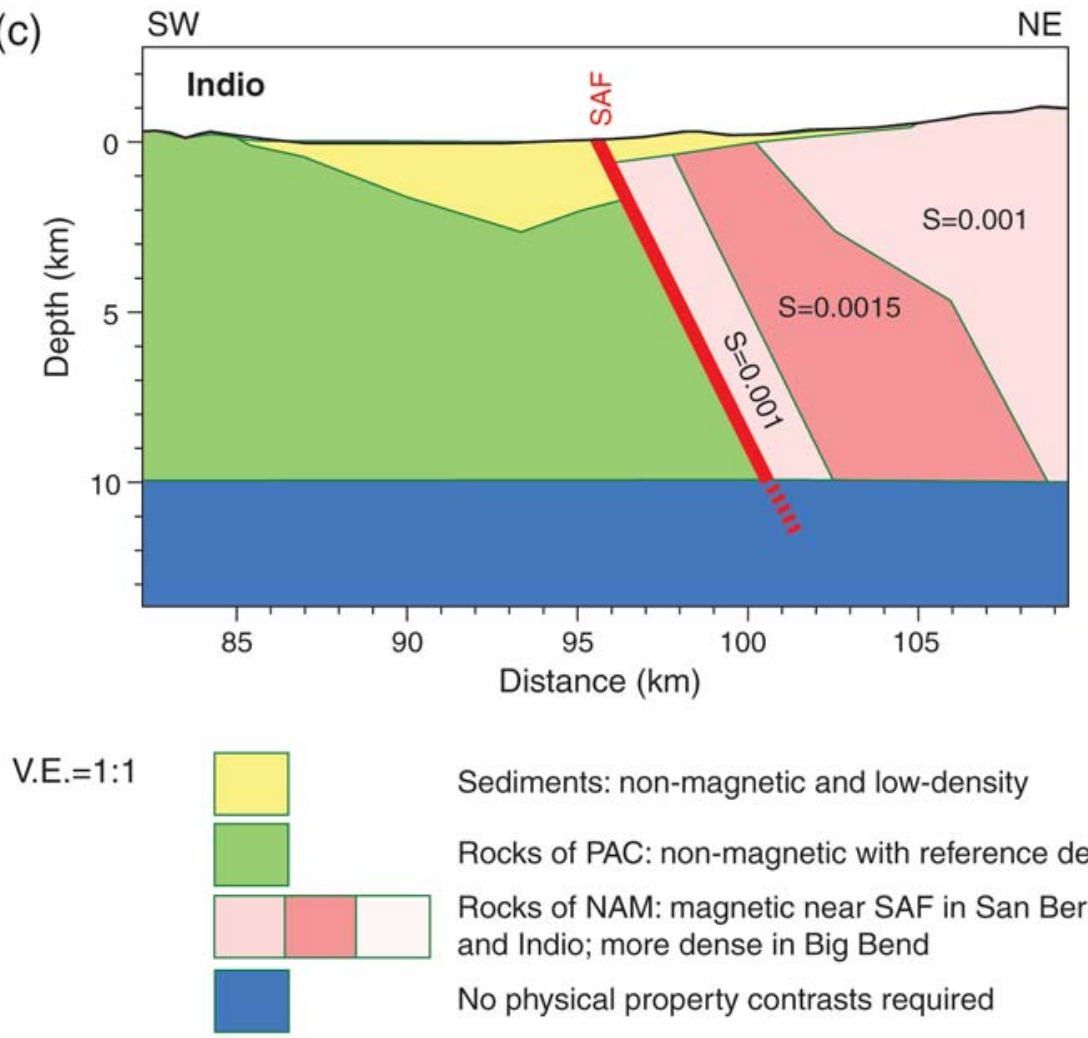

Sediments: non-magnetic and low-density

Rocks of PAC: non-magnetic with reference density of $2670 \mathrm{~kg} / \mathrm{m}^{3}$

Rocks of NAM: magnetic near SAF in San Bernardino and Indio; more dense in Big Bend

No physical property contrasts required

Figure 3. Block models for three sites along SAF. (a) Model of gravity data at the Big Bend of SAF (Griscom and Jachens, 1990). Location is profile 1 on Figure 1. D, density differences $\left(\mathrm{kg} / \mathrm{m}^{3}\right)$ of upper crustal rocks of North American plate (NAM) compared with Pacific plate (PAC, density $2670 \mathrm{~kg} / \mathrm{m}^{3}$ ). (See also modeling of combined gravity and aeromagnetic data at Big Bend in Appendix A.) (b, c) Block models of magnetic data at San Bernardino and Indio sites on SAF from this study. Locations are profiles 8 and 12 on Figure 1 . S, magnetic susceptibility $\left(10^{-3} \mathrm{cgs}\right.$ units). 
the San Bernardino and Little San Bernardino Mountains that lie adjacent to the SAF (Rogers, 1965, 1967; Jennings, 1977). Subsequent work in the Little San Bernardino Mountains has shown that these rocks are largely Jurassic and Cretaceous foliated igneous rocks (Wooden et al., 1994, 2001). This magnetic anomaly arises because the magnetic rocks are truncated on their southwest side by the SAF and juxtaposed against nonmagnetic rocks.

Modeling of these magnetic data reveals a surprisingly shallow northeast dip of $37 \pm 5^{\circ}$ at San Bernardino (Figs. 3b, 5) and a moderate northeast dip of $65 \pm 8^{\circ}$ (Figs. 3c, 6) at Indio. The positions and shapes of the magnetic anomaly along both profiles allow us to constrain the dip of the SAF. In modeling the magnetic data, we assume a planar contact between rocks having differing susceptibilities that intersects the land surface at the Holocene trace of the SAF. Physicalproperty measurements of basement rocks in these areas (Anderson et al., 2004; Langenheim and Powell, 2009) are used in our analysis.
The observed magnetic anomaly along the San Bernardino profile consists largely of a single, $400 \mathrm{nT}$ magnetic high that lies to the east of the trace of the SAF on the northeastern edge of San Bernardino Valley (Fig. 5). If the SAF were a vertical contact between nonmagnetic rocks of the San Gabriel Mountains-type basement (which includes the Pelona Schist) and magnetic rocks of the San BernardinoLittle San Bernardino Mountains-type basement, the resulting magnetic anomaly would be more dipolar than observed, with an anomaly peak about $2 \mathrm{~km}$ southwest of the observed magnetic peak (Fig. 5a). Modeling this contact dipping $37^{\circ}$ to the northeast produces a good match of both the placement of the magnetic peak and the monopolar shape of the anomaly (Fig. 5b). We determined the trade-off between the modeled SAF dip and the fit to the observed magnetic anomaly by calculating anomalies at a variety of dip values (Fig. 5c). This curve shows the best fit at $37^{\circ}$ with misfits that are statistically similar within a few degrees of that optimal dip value. By about $5^{\circ}$ on either side of that minimum, the predicted

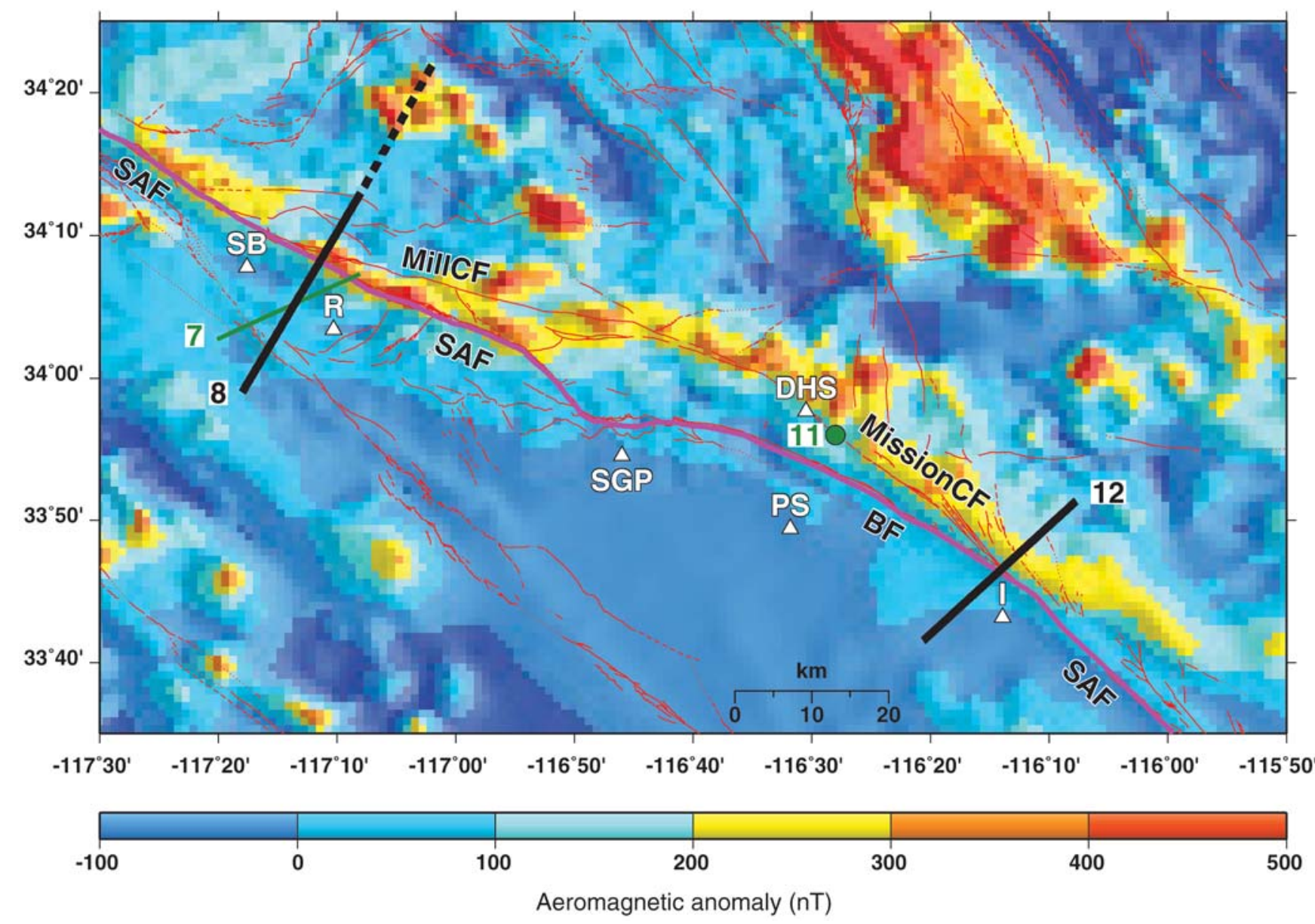

Figure 4. Aeromagnetic map of southern California from San Bernardino to Indio (from Bankey et al., 2002). Black lines, potential-field modeling profiles 8 and 12 of Figure 1 (dashed for northeast segment of profile 8 where data are not modeled; see Fig. 5); green line and green dot, seismic-imaging profiles 7 and 11 of Figure 1 (Catchings et al., 2008, 2009, respectively); thick magenta line, trace of SAF; and thin red lines, other Quaternary active faults (from http://earthquake.usgs.gov/hazards/qfaults/). BF, Banning fault; DHS, Desert Hot Springs; I, Indio; MillCF, Mill Creek fault; MissionCF, Mission Creek fault; PS, Palm Springs; R, Redlands; SB, San Bernardino; SGP, San Gorgonio Pass. 
(a)

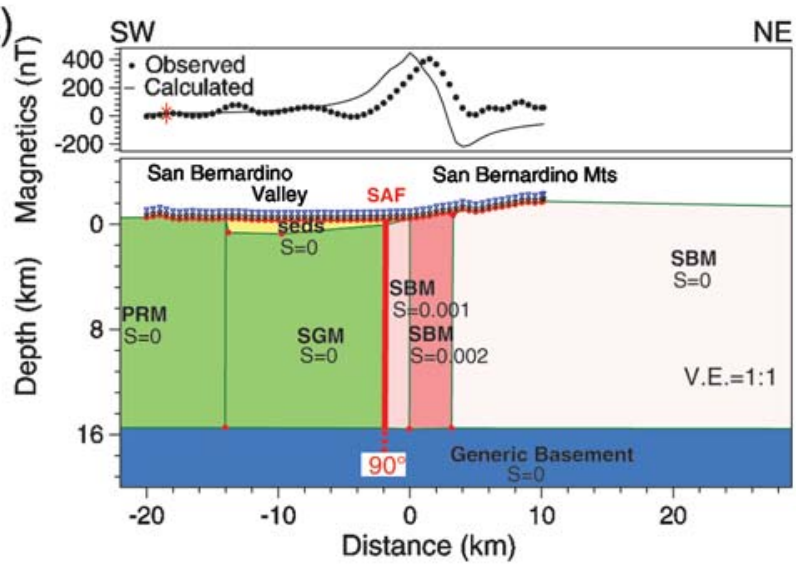

(b)

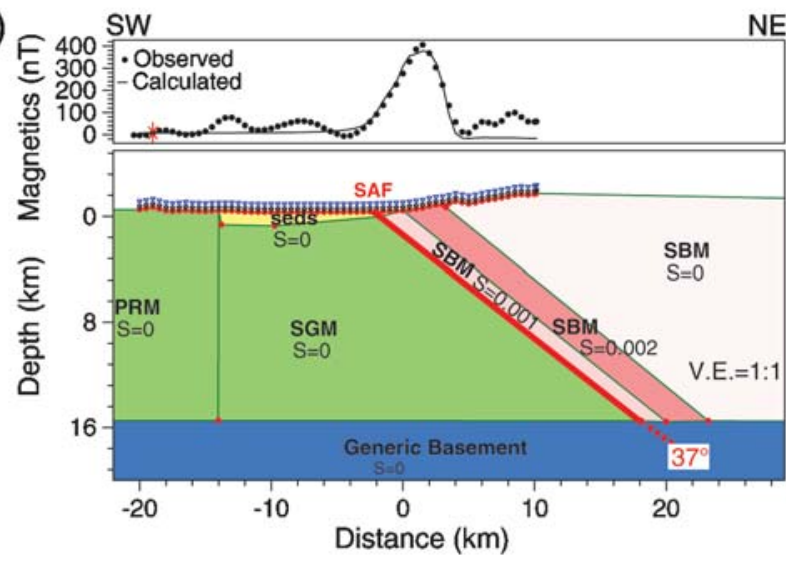

(c)

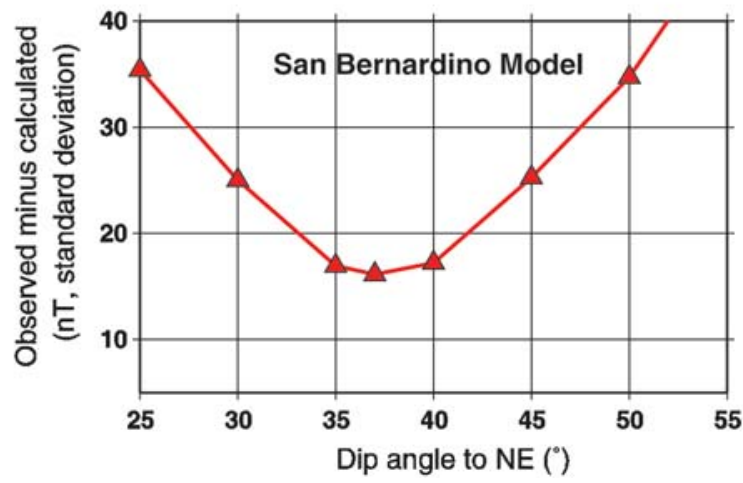

Figure 5. (a, b) Block models of San Bernardino site with SAF dips of $90^{\circ}$ and $37^{\circ}$. Location is profile 8 on Figure 1. Curves above block models are observed and calculated magnetic anomalies. (c) Curve showing trade-off between fault dip and standard deviation of difference between observed and calculated magnetic anomalies; dip of $37^{\circ}$ northeast is optimal. PRM, Peninsular Ranges-type basement; SGM, San Gabriel Mountains-type basement; SBM, San Bernardino Mountains-type basement; seds, sedimentary deposits. $\mathrm{S}$, magnetic susceptibility $\left(10^{-3} \mathrm{cgs}\right.$ units). Red stars are located where observed and calculated curves are constrained to agree.

magnetic anomalies are significantly worse than the optimal case. In this model, the magnetic boundary extends to $15 \mathrm{~km}$ depth, but this depth extent is not well constrained by the observed magnetic anomaly. If the depth extent is smaller, then (a)

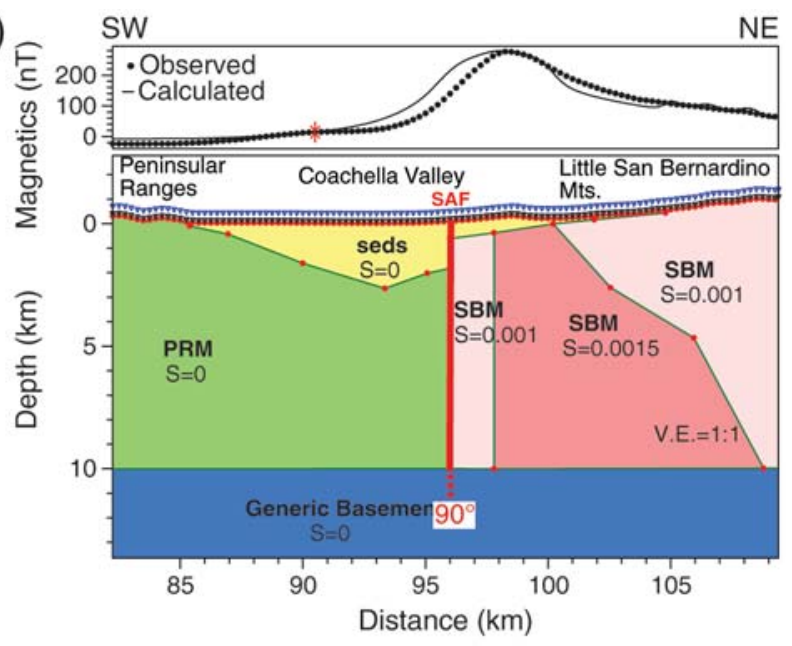

(b)

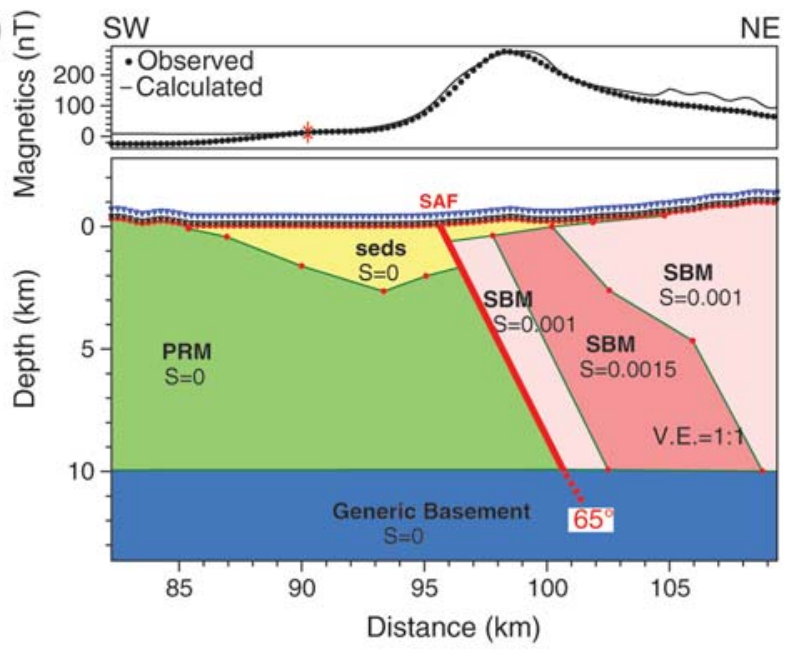

(c)

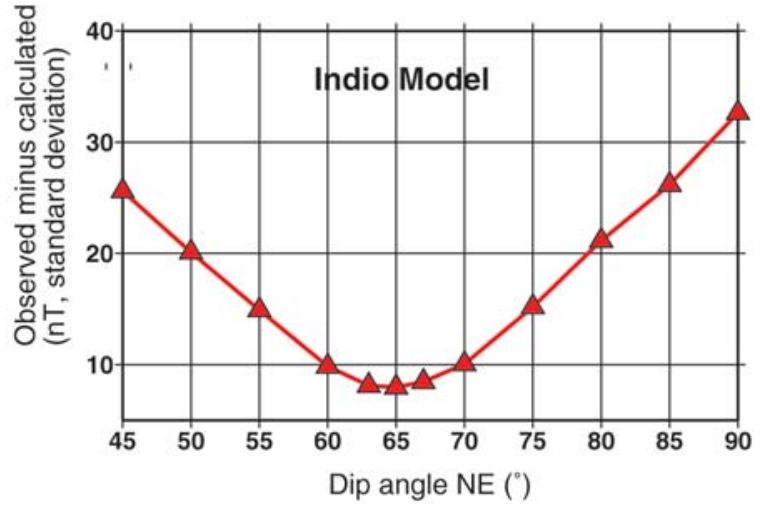

Figure 6. Magnetic modeling results for Indio site, presented in the same fashion as in Figure 5. Location is profile 12 on Figure 1. Optimal SAF dip is $65^{\circ}$ northeast.

the susceptibility would need to be proportionally higher to produce the same aeromagnetic anomaly; in cases of extremely high susceptibilities, the optimal SAF dip value might be less than previously discussed.

The observed magnetic anomaly on the Indio profile is about $250 \mathrm{nT}$ in magnitude and again lies just to the east 
of the trace of the SAF (Fig. 6). Basement rocks on the southwest side of the SAF are nonmagnetic rocks of the eastern Peninsular Ranges, and rocks on the northeast side are part of the magnetic San Bernardino-Little San Bernardino Mountains basement (see previous text). In this model, a dip of $65^{\circ}$ to the northeast produces a good match between the observed and modeled anomalies, with significantly worse fits beyond $\pm 7-8^{\circ}$.

In the San Bernardino and Indio areas, the gravity anomalies are governed primarily by the shape of the basins immediately to the southwest of the SAF (see Fig. 3b,c) and are not sensitive to the dip of the SAF. We have, therefore, not shown gravity modeling in Figures 5 and 6. In contrast, in the Big Bend area, the aeromagnetic data are primarily sensitive to the structure of the Eagle Rest Peak Gabbro, and are not sensitive to the dip of the SAF at our model location (see Appendix A).

It is important to note that the structural discontinuities modeled from potential-field data do not necessarily represent the currently active surface of the SAF; they could represent older faults. However, if such postulated older faults do not have exactly the same strike as the modern SAF, they should outcrop somewhere along strike, either northwest or southeast of our profiles, making a low angle with the SAF and paralleling a magnetic anomaly that diverges from the Holocene SAF. At San Bernardino, our modeled profile (Figs. 4, 5) approximately crosses the low-angle mapview junction between the late Quaternary Mill Creek fault and Holocene SAF (see Jennings, 1994). To the southeast of the modeled profile, the magnetic high follows the Holocene SAF rather than the Mill Creek fault (Fig. 4), indicating that the modeled magnetic boundary most likely is the Holocene SAF. At Indio, our modeled profile (Figs. 4, 6) crosses the SAF again at a low-angle junction between two branches of the SAF, the Mission Creek and Banning faults, both of which have had Holocene activity. To the northwest, the magnetic high follows the Mission Creek fault rather than the Banning fault, indicating that the modeled magnetic boundary is most likely the Mission Creek fault. We note that approximately $25 \mathrm{~km}$ northeast of our modeled profile, at Desert Hot Springs (Figs. 1, 4, location 11), the Mission Creek fault appears to dip steeply $\left(85^{\circ}\right)$ southwest in the upper $500 \mathrm{~m}$, based on the seismic-imaging results of Catchings et al. (2009), and it loses evidence for Holocene displacement (Jennings, 1994). Here, the Mission Creek fault appears to be in the hanging wall of the seismically active Banning fault (see next section).

\section{Seismicity}

The use of seismicity to define the SAF cannot be done in a simple, uniform way. Where the SAF is locked, from the northern Coachella Valley to Cholame, seismicity appears to be largely off the SAF. In the San Gabriel Mountains, for example, seismicity occurs largely in clusters on opposite sides of the SAF (Hauksson, 2000, pl. 3, panel d; Lin et al.,
2007, their fig. 13). Where the SAF is creeping, along the northeast side of the Salton Sea (see Data and Resources), relocated microseismicity aligns along a moderately northeast-dipping $\left(57^{\circ}-59^{\circ}\right)$ plane that projects to the surface at the SAF trace (Fig. 1, profiles 13, 14, and 15; Fig. 7; Lin et al., 2007). The tight planar distribution of hypocenters in this location resembles that commonly seen on other creeping faults (e.g., Rubin et al., 1999; Waldhauser and Ellsworth, 2002). Some focal mechanisms in this area support right lateral displacement on a dipping SAF. In addition, Fialko's (2006) InSAR observations of asymmetric strain accumulation across the SAF trace in this area support a northeast-dipping $\left(\sim 60^{\circ}\right)$ fault, if the crustal rigidity does not vary across the fault.

Between the locked and creeping sections of the SAF, in the northern Coachella Valley, two large earthquakes with aftershock sequences that extend through the seismogenic crust (upper $15 \mathrm{~km}$ ) are interpreted to outline the active surface of the SAF: the $1948 M_{L}$ 6.3 Desert Hot Springs earthquake (Nicholson, 1996) and the $1986 M_{\mathrm{w}} 6.1$ North Palm Springs earthquake (Jones et al., 1986). The North Palm Springs sequence (Fig. 1, profile 10) provides the better constraints; the focal mechanism and aftershocks agree on a moderate northeast dip of $45^{\circ}$ and $52^{\circ}$, respectively (Fig. 8). The Desert Hot Springs sequence provides poorer constraints; the focal mechanism indicates a northeast dip of $65^{\circ}-70^{\circ}$, but no clear fault dip is apparent from the aftershocks, most likely because of sparser seismic coverage at that time. These two aftershock sequences abut one another.

The SAF is not illuminated by seismicity between the North Palm Springs sequence and central California (Cholame). Significantly, however, our model SAF surface (Fig. 2) does separate areas with different seismicity characteristics on the North American and Pacific plates (NAM and PAC, respectively; Fig. 9). At the Big Bend, in the western Transverse Ranges (Fig. 1, profile 2), our model SAF surface separates moderate seismicity in crust of the NAM from sparser and shallower seismicity in the PAC crust (Fig. 9a).
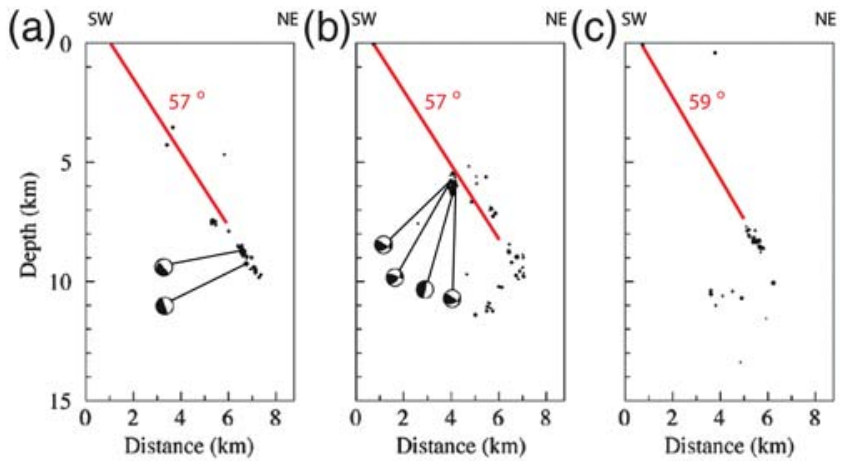

Figure 7. Seismicity cross sections across creeping section of SAF (Lin et al., 2007, their fig. 14). Locations are from profiles (a) 13 , (b) 14 , and (c) 15 on Figure 1. Compressional quadrants of far hemispheres of focal mechanisms are blackened. 
(a)

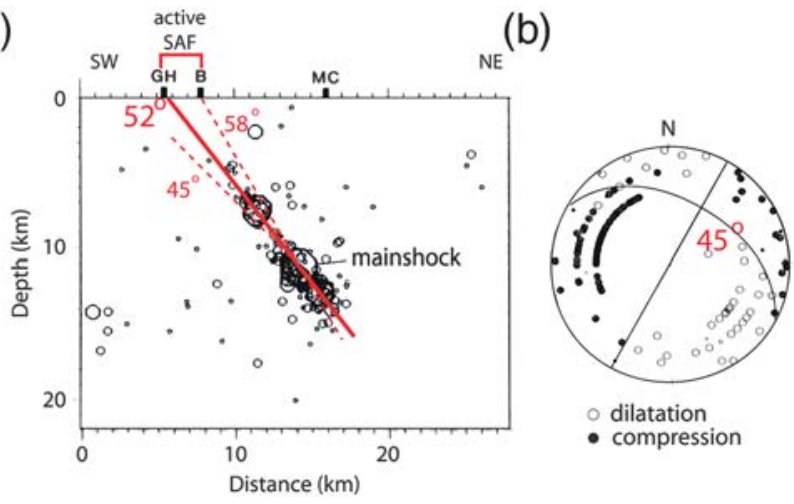

Figure 8. (a) Aftershocks of the $1986 M_{\mathrm{w}} 6.1$ North Palm Springs earthquake (Jones et al., 1986, their fig. 3A). Location is profile 10 on Figure 1. (b) Plan view of mainshock focal mechanism (Jones et al., 1986, their fig. 4). GH, Garnet Hill fault; B, Banning fault; MC, Mission Creek fault. GH, B, and MC are branches of SAF (Jennings, 1994). Cracks were observed along Banning fault after the 1986 earthquake but were not interpreted as surface rupture (Sharp et al., 1986).

Conversely, in the eastern San Gabriel Mountains (Fig. 1, profile 6), the model surface separates moderate seismicity in crust of the PAC from very sparse activity in NAM crust (Fig. 9b). In the San Gorgonio Pass area (Fig. 1, profile 9), our model SAF surface passes through or near the step in the base of seismicity described by Nicholson et al. (1986) and Magistrale and Sanders (1996) (Fig. 9c). Other authors have proposed that the SAF surface passes through this seismicity step (Yule and Sieh, 2003; Carena et al., 2004). Seismicity on the insides of both of the major bends in the SAF trace is deeper and extends beyond the surface trace of the SAF to locations beneath the opposing plate.

\section{Seismic Imaging}

The SAF can be traced into the lower crust as a velocity and reflectivity discontinuity in the crustal-scale images from the Los Angeles Region Seismic Experiment (LARSE; Ryberg and Fuis, 1998; Fuis et al., 2001; Godfrey et al., 2002; Fuis et al., 2003, 2007) (Fig. 1, profiles 4, 5; Fig. 10). Reflectivity includes wide-angle reflections (Fig. 10a,b, heavy black lines), near-vertical-incidence reflections (Fig. 10a, blue lines), or near-vertical-incidence reflective zones (Fig. 10b, blue zones A and B) (Ryberg and Fuis, 1998; Fuis et al., 2001, 2003, 2007). Reflectivity south of the SAF is interpreted to constitute one or more active decollements that originate at the SAF and splay upward into active reverse faults (including blind reverse faults) beneath the Los Angeles region. The $1971 M_{\mathrm{w}} 6.7$ San Fernando and $1987 M_{\mathrm{w}} 5.9$ Whittier Narrows earthquakes occurred on two such faults. The dip of the SAF through the crust is $90^{\circ}$ on LARSE line II (LARSE II; Fig. 10a) and $83^{\circ}-90^{\circ}$ on LARSE line I (LARSE I; Fig. 10b). On both lines the uncertainty in dip is approximately $5^{\circ}-7^{\circ}$. On LARSE I, reflectivity (Fig. 10b, blue zone A and the adjacent heavy black lines) extends north of the surface trace, leading to an interpretation of an $83^{\circ}$ northeastward dip, but the northward termination of the reflectivity is uncertain within a few $\mathrm{km}$. Modeling of gravity and magnetic data suggests that the SAF dip on LARSE I is $90^{\circ}$, with an uncertainty of a few degrees (Langenheim, 1999).

\section{Upper-Mantle High-Velocity Body}

A number of authors have imaged a prominent body in the upper mantle of southern California with $\leq 3 \%$ higher $P$-wave velocity than average (Hadley and Kanamori, 1977; Raikes, 1980; Humphreys et al., 1984; Humphreys and Clayton, 1990; Kohler, 1999; Kohler et al., 2003; Schmandt and Humphreys, 2010). In Figures 1 and 11, we reproduce the HVB image of Kohler et al. (2003), obtained from a study of teleseisms recorded both on regional stations of the southern California seismic network and on temporary stations deployed along or near the LARSE lines. The HVB extends $\sim 250 \mathrm{~km}$ east-west through the Transverse Ranges (Fig. 1; horizontal slice [blue patch] is at 110-km depth; see also Kohler et al., 2003, their fig. 7a). It appears to cross the surface trace of the SAF obliquely, and it extends to more than 200-km depth. Tests show that horizontal resolution of this tomographic model is good at a length scale of 15-20 km (Kohler, 1999; Kohler et al., 2003). The vertical resolution is less well known, with smearing expected from the steeply traveling imaging rays; however, smearing is probably not extreme because features with various dips can be seen in cross sections (Fig. 11). A shear-wave HVB image has also been produced from Rayleigh-wave tomography (Yang and Forsyth, 2006), although the model indicates a depth extent for the HVB of only $150 \mathrm{~km}$. Schmandt and Humphreys (2010) have imaged this body with both teleseismic $P$ and $S$ waves using approximate 3D sensitivity kernels in three frequency bands. The HVBs imaged by both $P$ and $S$ waves are very similar to one another, and the $V_{P} / V_{S}$ image is also similar to the $P$ - and $S$-wave images, with the HVB showing a $V_{P} / V_{S}$ ratio that is $2 \%-3 \%$ lower than the average of the regional $1 \mathrm{D}$ velocity model they are using (see references for this model in Schmandt and Humphreys, 2010). Cross sections through their $P$-wave model near the cross sections of Figure 1, show the same basic features as in Figure 11 (B. Schmandt, written commun., 2009). Their image shows a base of the HVB at approximately $200 \mathrm{~km}$.

In Figure 11, we fit by eye planar zones (shown by a horizontally ruled pattern) along the boundary between highand low-velocity contours on the north side of the HVB. We ignore short-wavelength features $(<15-20 \mathrm{~km})$, given the horizontal resolution length scale for $P$-wave tomography described previously. We also speculate that there may be a similar zone extending northward and downward into the mantle from the Garlock fault (Fig. 11a). The HVB terminates westward in the Big Bend region (Fig. 1, blue patch), giving rise to an irregular cross section in Figure 11a, but the overall impression is of a southwest dip of the velocity transition zone. The planar zones we have interpreted may 
(a)

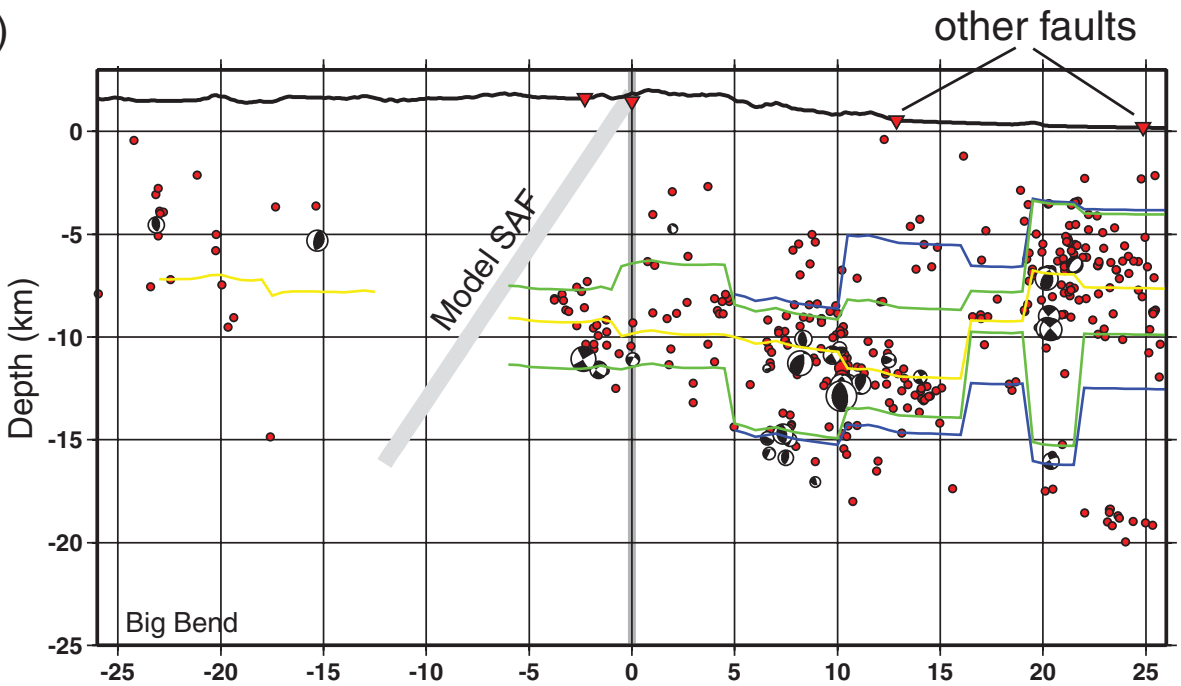

(b)

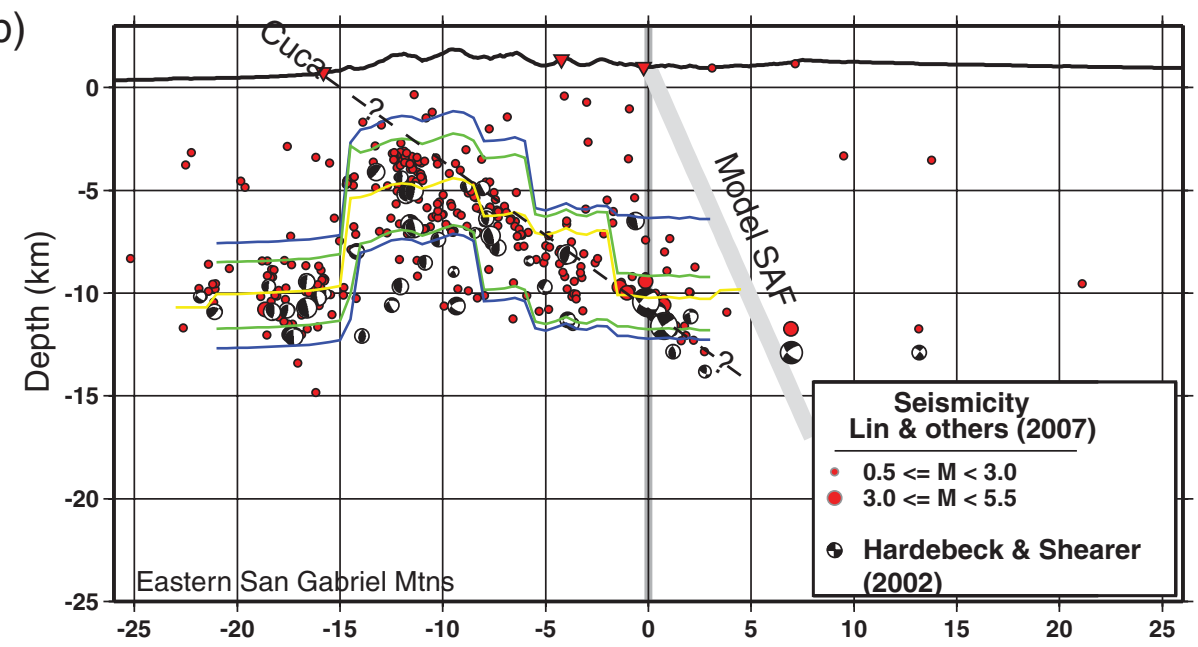

(c)

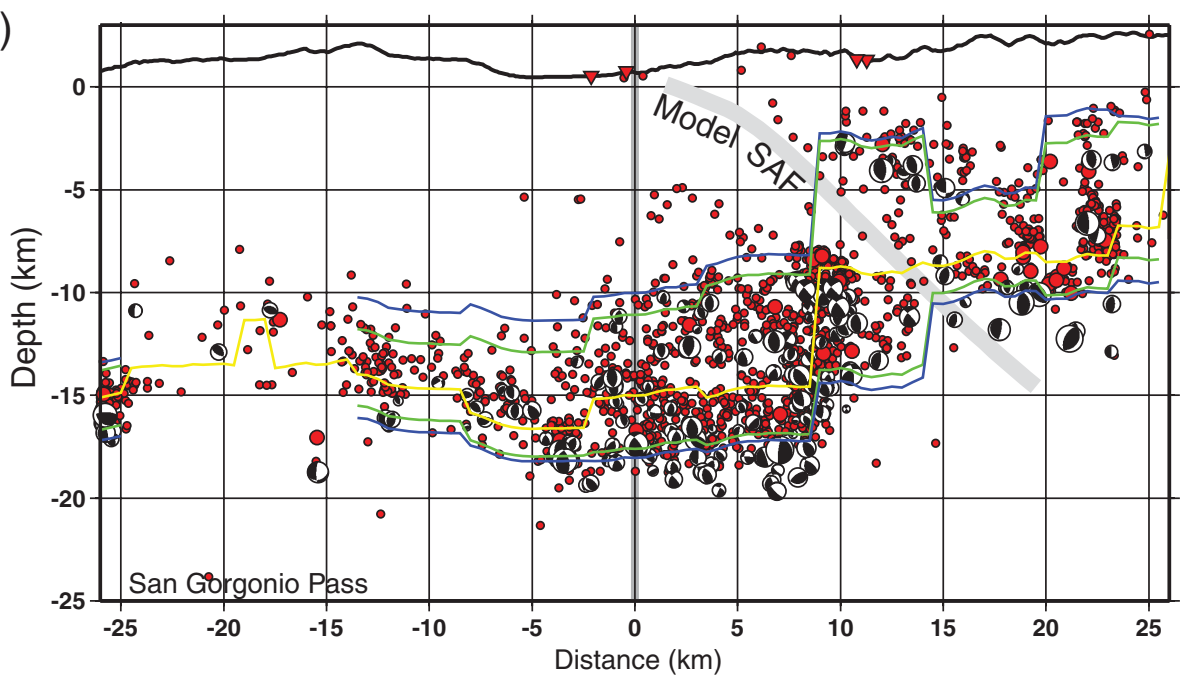

Figure 9. Seismicity cross sections across SAF at three locations within locked zone between Cholame and Coachella Valley. Locations are profiles (a) 2, (b) 6, and (c) 9 on Figure 1. Hypocenters are taken from Lin et al. (2007) and projected from $\pm 2 \mathrm{~km}$, and focal mechanisms are taken from Hardebeck and Shearer (2002). The latter have been moved slightly to conform with hypocenters of Lin et al. (2007). Percentages of hypocenters with depth $(5,10,50,90,95 \%)$ are contoured in 2.5-km wide columns. Model SAF surface from this study is superposed (gray line). Note in (c) we have blended results from modeling SAF in upper few km (Langenheim et al., 2005) with a deep SAF surface that is extrapolated between profiles presented in this study at North Palm Springs and San Bernardino. Cuca, Cucamonga thrust fault. 
(a) $\mathrm{s}$

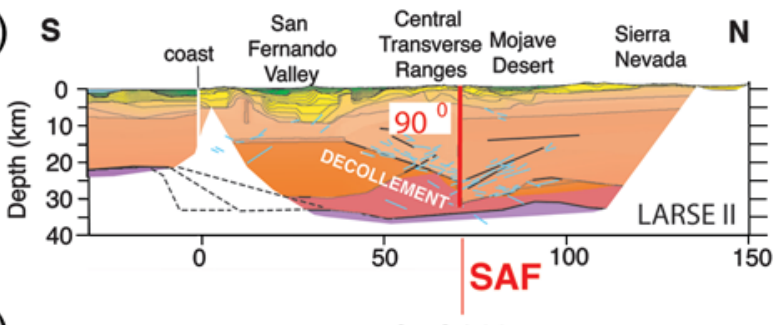

(b)

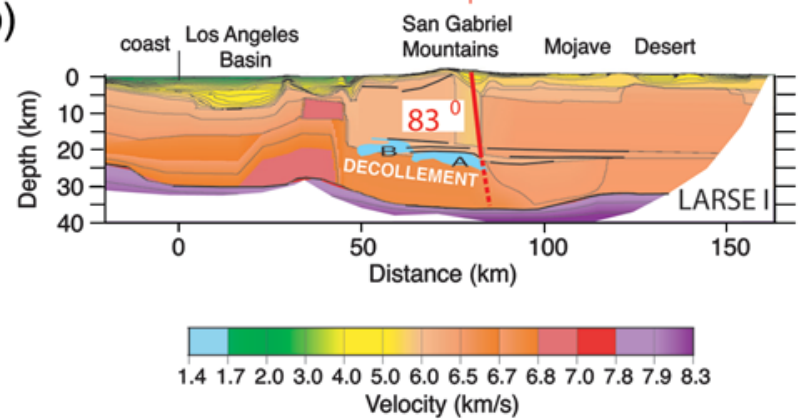

Figure 10. Velocity models for LARSE lines II (a) and I (b) (Fuis et al., 2007). Locations are profiles 4 and 5 on Figure 1. Heavy black lines, wide-angle reflections, dashed where inferred; blue lines, near-vertical-incidence reflections (LARSE II); blue patches ("A" and "B") near-vertical-incidence reflectivity zones (LARSE I). SAF is delineated by discontinuities in both velocity and reflectivity. Reflectivity is interpreted to reveal active midcrustal decollements south of SAF (Fuis et al., 2001, 2003).

denote mantle shear zones similar to the SAF in the crust or they may arise from gradients of material flow within the mantle.

When SAF and Moho features of LARSE I and II (Fig. 10) are superimposed on slices through the tomographic model of the HVB (Fig. 11b,c), the SAF intersects the Moho at the north side of the HVB (Fuis et al., 2007). In three other locations (Fig. 1, profiles 1, 8, and 10), where the SAF is characterized only in the upper crust, the SAF projects downward to intersect the Moho at or near the north side of the HVB (Fig. 11a,d,e). The largest mismatch is for the North Palm Springs cross section (Fig. 11e), where the SAF projection is $\sim 15 \mathrm{~km}$ south of the north boundary of the HVB. One can estimate the probability that in five cases, the SAF should fall within $\sim 15 \mathrm{~km}$ of the north side of the HVB as follows: the probability that the SAF projects by random chance into the $\sim 15-\mathrm{km}$-wide bin nearest the northern edge of the $\sim 60-\mathrm{km}$-wide HVB is 1 in 4 at a single site. The probability that it projects in this manner in all five cases is $\sim 1$ in $1000\left(1 / 4^{5}\right)$. This argument assumes a causal connection between the SAF and footprint of the HVB. If there is no such connection, then the correlation of the SAF and north side of the HVB in these five cases is even less probable. This argument also assumes that the five profiles yield measures of SAF structure that are independent of one another, which is difficult to quantify with profile models derived from heterogeneous data. Notwithstanding the difficulty in quantifying a probability value, the spatial correlation of the crustal SAF with the north side of the HVB is likely real.

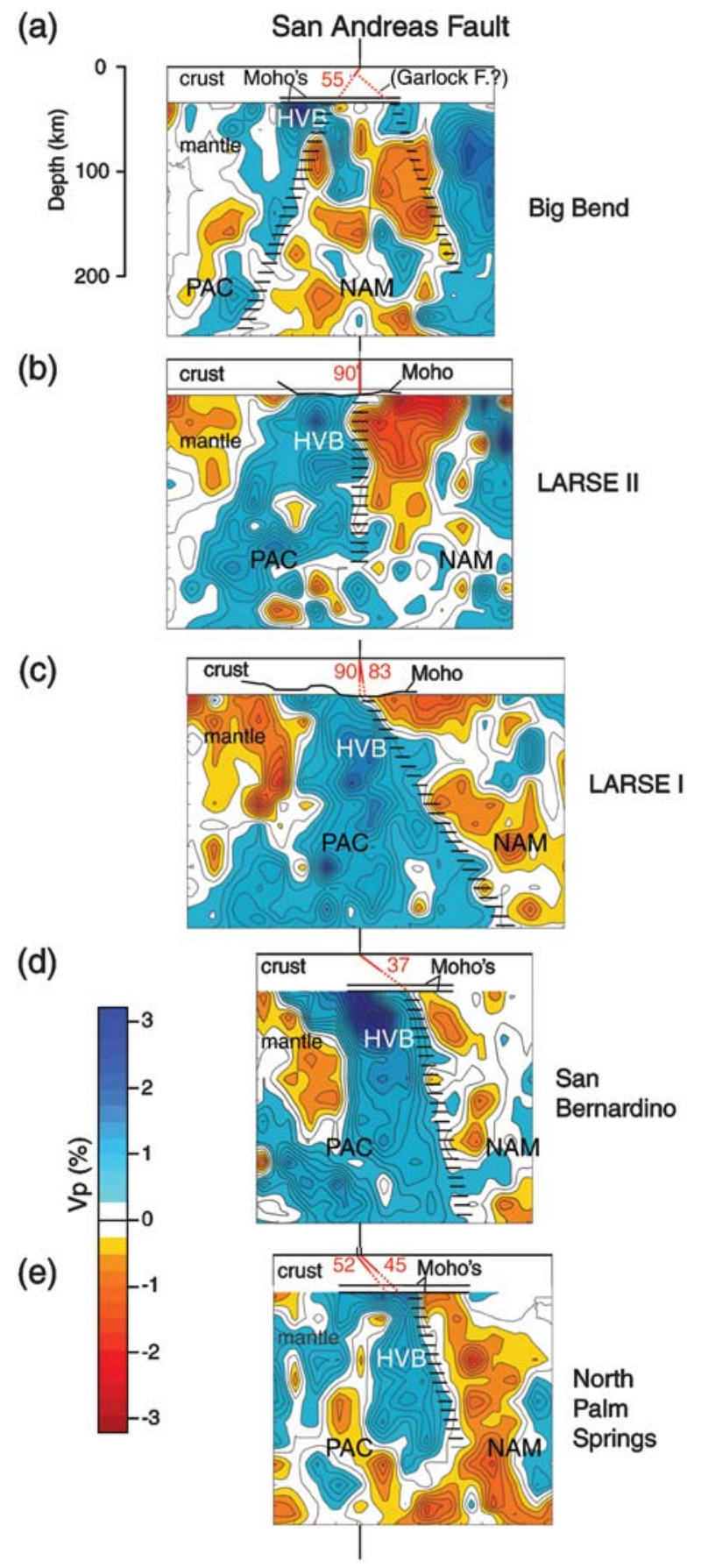

Figure 11. Cross sections through crust and upper-mantle of California showing SAF in crust (red lines, dotted where projected downward) and north side of HVB (horizontal ruling). Locations are along profiles (a) 1, (b) 4, (c) 5, (d) 8, and (e) 10 on Figure 1. North side of HVB was determined by eye to lie along transition from positive to negative, long-wavelength $(100 \mathrm{~km})$ seismic velocity anomalies. Color changes represent perturbations from background velocity model (Kohler, 1999; Kohler et al., 2003). In most cases, north side of HVB is also marked by high $P$-wave velocity gradient. Moho, heavy black lines; alternate Moho depths are shown for locations other than LARSE I and II. Note that SAF in crust intersects north side of HVB at Moho to within $15 \mathrm{~km}$ or less. PAC, Pacific plate; NAM, North America plate. Zero on color scale is $V_{P}=7.8 \mathrm{~km} / \mathrm{s}$ at $40-\mathrm{km}$ depth and $V_{P}=8.2 \mathrm{~km} / \mathrm{s}$ at $200-\mathrm{km}$ depth. No vertical exaggeration. 


\section{Discussion}

Supporting Data from the San Bernardino Region

The dip of $37 \pm 5^{\circ}$ at San Bernardino (Fig. 5) was a surprising result of this study. To further test this result, we modeled magnetic data along the seismicity profile of Figure 9b in the eastern San Gabriel Mountains (Fig. 1, profile 6 ), between the LARSE I and San Bernardino locations. The magnetic data support a northeast dip of $60^{\circ}-80^{\circ}$ (Appendix A) as predicted by our dipping SAF model (Fig. 2). Seismicity along this profile shows thrust mechanisms, likely related to the Cucamonga thrust fault, that occur directly below the trace of the SAF, supporting the interpretation that the SAF dips northeast here (Fig. 9b). Surficial geology also supports a northeast dip in this area, including studies by Meisling and Weldon (1989) and a trench study shown by McGill et al. (2008). Meisling and Weldon (1989) map a northeast dip in outcrops in this area. In addition, they appeal to a northeast step or bulge of the SAF at depth to explain a northwestward migration of mid-Pleistocene uplift of crystalline rocks in the westernmost San Bernardino Mountains (hanging wall) adjacent to the SAF. The geometric effects of such a step or bulge are not significantly different from those of a fault whose dip decreases from vertical to shallower values from the Mojave Desert to San Bernardino. Catchings et al. (2008) observe a possible expression of the SAF near the northeastern end of their San Bernardino Valley seismic reflection profile, which crosses the SAF near our magnetic model (Fig. 1, profile 7; Fig. 4). While the seismic reflection imaging is poorly resolved near the northeast end of their seismic line, Catchings et al. (2008) interpret a shallow, northeast dip of the SAF consistent with our magnetic model results. Finally, Dair and Cook (2009) simulate geologic deformation in the San Gorgonio Pass area, southeast of San Bernardino, with 3D numerical models of the SAF. They conclude that in this area a north-dipping fault matches observations of strikeslip and uplift rates better than a vertical SAF.

\section{Paleoseismic Investigations}

Most paleoseismic trenching investigations are not ideally suited for providing a definitive dip for the SAF. First, trenches are usually dug in areas of high sedimentation, where the fault commonly diverges into numerous branches as it approaches the surface. Also trenches are commonly dug in structurally complex graben areas, where the bounding faults dip in opposite directions. For example, at Indio (near our Indio profile, Fig. 1), two breaks of the SAF on opposite sides of a reverse graben, in a step-over region, dip in opposite directions: $50^{\circ}-65^{\circ}$ southwest on the southwest side of the graben and $60^{\circ}-65^{\circ}$ northeast on the northeast side of the graben (Philibosian et al., 2009). In the San Bernardino area, trenching reported by McGill et al. (2008) and S. McGill (written commun., 2010), reveals two sets of northeastdipping Holocene faults within a few-meter interval in the trench, with dips of $25^{\circ}$ northeast for the southwest set and $70^{\circ}$ northeast for the northeast set. In the Big Bend area, trenching has produced ambiguous data on the dip of the SAF, although most of the early trenching by Davis (1983) tends to support a moderate southwest dip (Appendix B).

\section{Tomographic Images of the Crust from Earthquakes}

Tomographic velocity models of the crust produced chiefly from earthquake data do not currently have the resolution to provide information on the dip of the SAF, where it is defined by a velocity contrast. Horizontal node spacing for $P$-wave models range from 10 to $15 \mathrm{~km}$ (Lin et al., 2010 and Hauksson, 2000, respectively), and the minimum horizontal scale length for an $S$-wave model that covers a significant segment of the SAF is $20 \mathrm{~km}$ (Tape et al., 2010). It is interesting that the $S$-wave velocity model of Tape et al. (2010) does suggest a vertical/steep SAF in the Mojave Desert area, similar to our model.

\section{Origin of the HVB}

The apparent connection of the SAF to the north side of the HVB suggests that features of the plate boundary can be traced into the mantle and that the HVB belongs chiefly or wholly to the PAC (Fuis et al., 2007). If so, then the HVB may represent oblique downwelling of the PAC along the plate boundary, such as that seen in finite-element-modeling of continent-continent collisions (Pysklywec et al., 2000). Seismic properties of the HVB, including possible anisotropy, may be used to evaluate the hypothesis that the HVB represents oblique downwelling of the PAC along the plate boundary, but at this time, this hypothesis cannot be confirmed or dismissed (Appendix C).

\section{Seismic Hazard}

The propeller shape of the SAF proposed in this study has implications for seismic hazards. In models of peak ground acceleration (PGA) and peak ground velocity (PGV) that have been produced for the Next Generation Attenuation project (Stewart et al., 2008), the distance from an earthquake rupture to a given land-surface site is, of course, smaller on the side toward which the rupture surface dips, that is, in the hanging wall of the fault. Because PGA and PGV vary inversely with distance, these values are larger on the hanging wall than on the footwall of the fault. This observation is born out for both the $1986 M_{\mathrm{w}} 6.1$ North Palm Springs earthquake, which involved strike-slip rupture on a dipping fault plane, and the $1989 M_{\mathrm{w}} 6.9$ Loma Prieta earthquake, which involved oblique rupture on a dipping fault plane. In both cases, ground motion was markedly asymmetric about the surface projection of the rupture, with the greatest motions on the hanging wall. For both the North Palm Springs event (dip $45^{\circ}-50^{\circ}$ northeast; see Data and Resources) and the Loma Prieta event (Plafker and Galloway, 1989; their fig. 17; $\operatorname{dip} 70^{\circ}$ southwest), PGA on the hanging wall was about double that at sites an approximately equal distance from the 
fault trace on the footwall. Thus, if our model of the southern SAF is accurate, it will be important to recalculate shaking from ShakeOut (Jones et al., 2008; Perry et al., 2008) and other scenario earthquakes given the systematic and significant dip variations of the SAF presented here.

\section{Summary}

The SAF is significantly nonvertical near its bends in the Transverse Ranges. It dips away from the bends, resulting in a propeller-like shape. The SAF in the crust appears to connect with the north side of the HVB at the Moho, and the north side of the HVB is potentially a continuation of the plate boundary into the mantle. The HVB may be an oblique downwelling of PAC lithosphere, but this hypothesis cannot be confirmed or dismissed at this time. While most of the southern SAF is not illuminated in seismicity catalogs, our dipping SAF model separates differing seismicity regimes in the NAM and PAC better than does a vertical SAF.

Future research would benefit from more seismicimaging and potential-field modeling of the SAF. Numerical deformation modeling of the SAF and related faults would provide insight to how the plates move past one another along this propeller-shaped boundary. Ground-motion calculations based on our interpreted SAF geometry throughout southern California would be useful to compare with existing calculations that are based on a vertical SAF in most places.

\section{Data and Resources}

Documentation of creep on the southern SAF was found at Cooperative Institute for Research in Environmental Sciences, University of Colorado; Roger Bilham's web site for Durmid Creepmeters, along the northeast shore of the Salton Sea, southern California (http://cires.colorado.edu/ bilham/creepmeter; last accessed August 2011).

PGA came from COSMOS Strong Motion Program Members, Consortium of Organizations for Strong-Motion Observation Systems Virtual Data Center (http://db.cosmos-eq.org/ scripts/event.plx?evt=40; last accessed August 2011).

Faults in Figure 4 came from U.S. Geological Survey and California Geological Survey, 2006, Quaternary fault and fold database for the United States (http://earthquake. usgs.gov/regional/qfaults; last accessed June 2010).

\section{Acknowledgments}

We thank many colleagues for discussions, including Peter Bird, Nik Christensen, Paul Davis, Don Forsyth, Ruth Harris, Egill Hauksson, Gene Humphreys, Craig Nicholson, David Okaya, Mike Oskin, Thomas Parsons, Martin Scherwath, Brandon Schmandt, Peter Shearer, Paul Spudich, Bill Stuart, Uri ten Brink, Doug Wilson, and George Zandt. We thank Jeanne Hardebeck, Rick Blakely, Haijiang Zhang, and an anonymous reviewer for helpful reviews.

\section{References}

Anderson, M., J. C. Matti, and R. C. Jachens (2004). Structural model of the San Bernardino basin, California, from analysis of gravity, aeromagnetic, and seismicity data, J. Geophys. Res. 109, B04404, 20, doi 10.1029/2003JB002544.

Babuska, V., and M. Cara (1991). Seismic Anisotropy in the Earth, Kluwer Academic Publishers, Boston, Massachusetts, 217 pp.

Bankey, V., A. Cuevas, D. Daniels, C. A. Finn, I. Hernandez, P. Hill, R. Kucks, W. Miles, M. Pilkington, C. Roberts, W. Roest, V. Rystrom, S. Shearer, S. Snyder, R. Sweeney, J. Velez, J. D. Phillips, and D. Ravat (2002). Digital data grids for the magnetic anomaly map of North America, U.S. Geol. Surv. Open-File Rept. 02-414, U.S. Geological Survey, Denver, Colorado, USA (http://pubs.usgs.gov/of/2002/ofr-02-414/).

Biasi, G. P. (2009). Lithospheric evolution of the Pacific-North American boundary considered in three dimensions, Tectonophysics 464, 43-59.

Carena, S., J. Suppe, and H. Kao (2004). Lack of continuity of the San Andreas fault in southern California: Three-dimensional fault models and earthquake scenarios, J. Geophys. Res. 109, B04313, doi 10.1029/2003JB002643.

Catchings, R. D., M. J. Rymer, M. R. Goldman, and G. Gandhok (2009). San Andreas fault geometry at Desert Hot Springs, California, and its effects on earthquake hazards and groundwater, Bull. Seismol. Soc. Am. 99, 2190-2207, doi 10.1785/0120080117.

Catchings, R. D., M. J. Rymer, M. R. Goldman, G. Gandhok, and C. E. Steedman (2008). Structure of the San Bernardino basin along two seismic transects: Rialto-Colton fault to the San Andreas fault and along the I-215 freeway (I-10 to SR30), U.S. Geol. Surv. Open-File Rept. 2008-1197, 129 pp.

Crouch, J. K., and J. Suppe (1993). Late Cenozoic tectonic evolution of the Los Angeles basin and inner California borderland: A model for core complex-like crustal extension, Bull. Geol. Soc. Am. 105, 1415-1434.

Dair, L., and M. L. Cooke (2009). San Andreas fault geometry through the San Gorgonio Pass, California, Geology 37, 119-122, doi 10.1130/ G25101A.1.

Davis, T. (1983). Late Cenozoic structure and tectonic history of the western "Big Bend" of the San Andreas fault and adjacent San Emigdio Mountains: Santa Barbara, Ph.D. Thesis, University of California, 509 pp.

Davis, P. M. (2003). Azimuthal variation in seismic anisotropy of the southern California uppermost mantle, J. Geophys. Res. 108, no. B1, 2052, doi 10.1029/2001JB000637.

Fialko, Y. (2006). Interseismic strain accumulation and the earthquake potential on the southern San Andreas fault system, Nature 441, 968-971, doi 10.1038/nature04797.

Fuis, G. S., T. Ryberg, N. J. Godfrey, D. A. Okaya, and J. M. Murphy (2001). Crustal structure and tectonics from the Los Angeles basin to the Mojave Desert, southern California, Geology 29, 15-18.

Fuis, G. S., R. Clayton, P. Davis, T. Ryberg, W. Lutter, D. Okaya, E. Hauksson, C. Prodehl, J. Murphy, M. Benthien, S. Baher, M. Kohler, K. Thygesen, G. Simila, and G. Keller (2003). Fault systems of the 1971 San Fernando and 1994 Northridge earthquakes, southern California: Relocated aftershocks and seismic images from LARSE II, Geology 31, no. 2, 171-174.

Fuis, G. S., M. D. Kohler, M. Scherwath, U. ten Brink, H. J. A. Van Avendonk, and J. M. Murphy (2007). A comparison between the transpressional plate boundaries of the South Island, New Zealand, and southern California, USA: The Alpine and San Andreas fault systems, in A Continental Plate Boundary: Tectonics at South Island, New Zealand D. Okaya, T. Stern, and F. Davey (Editors), American Geophysical Union Monograph, 175, 307-327, doi 10.1029/175GM16.

Godfrey, N. J., G. S. Fuis, V. Langenheim, D. A. Okaya, and T. M. Brocher (2002). Lower crustal deformation beneath the central Transverse Ranges, southern California: Results from the Los Angeles Region Seismic Experiment, J. Geophys. Res. 107, no. B7, doi 10.1029/ 2001JB000354.

Griscom, A., and R. C. Jachens (1990). Crustal and lithospheric structure from gravity and magnetic studies, in The San Andreas Fault System, 
California, R. E. Wallace (Editor), U.S. Geol. Surv. Profess. Pap. 1515, 239-259.

Griscom, A., and H. W. Oliver (1980). Isostatic gravity highs along the west side of the Sierra Nevada and Peninsular Ranges batholiths, Eos Trans. $A G U$ 61, 1126, abstract.

Hadley, D., and H. Kanamori (1977). Recent seismicity in the San Fernando region and tectonics in the west-central Transverse Ranges, California, Bull. Seismol. Soc. Am. 68, 1449-1457.

Hardebeck, J. L., and P. M. Shearer (2002). A new method for determining first-motion focal mechanisms, Bull. Seismol. Soc. Am. 92, 2264-2276.

Hauksson, E. (2000). Crustal structure and seismicity distribution adjacent to the Pacific and North America plate boundary in southern California, J. Geophys. Res. 105, no. B6, 13,975-13,903.

Hearn, T. (1984). Pn travel times in southern California, J. Geophys. Res. 89, B3, 1843-1855.

Houseman, G. A., and P. Molnar (1977). Gravitational (Rayleigh-Taylor) instability of a layer with non-linear viscosity and convective thinning of the continental lithosphere, Geophys. J. Int. 128, 125-150.

Houseman, G. A., E. A. Neil, and M. D. Kohler (2000). Lithospheric instability beneath the Transverse Ranges of California, J. Geophys. Res. 105, no. B7, 16,237-16,250.

Humphreys, E. D. (1995). Post-Laramide removal of the Farallon slab, western United States, Geology 23, 987-990.

Humphreys, E. D., and R. W. Clayton (1990). Tomographic image of the southern California mantle, J. Geophys. Res. 95, 19,725-19,746.

Humphreys, E. D., R. W. Clayton, and B. H. Hager (1984). A tomographic image of mantle structure beneath southern California, Geophys. Res. Lett. 11, no. 7, 625-627.

Jennings, C. W. (1977). Geologic map of California, California Division of Mines and Geology, Sacramento, California, scale 1:750,000.

Jennings, C. W. (1994). Fault activity map of California and adjacent areas, California Division of Mines and Geology, Sacramento, California, scale $1: 750,000$.

Jones, L. M., R. Bernknopf, D. Cox, J. Golz, K. Hudnut, D. Mileti, S. Perry, D. Ponti, K. Porter, M. Reichle, H. Seligman, K. Shoaf, J. Treiman, and A. Wein (2008). The ShakeOut Scenario, U.S. Geol. Surv. OpenFile Rept. 2008-1150, 308 pp.

Jones, L. M., L. K. Hutton, D. D. Given, and C. R. Allen (1986). The North Palm Springs, California, earthquake sequence of July 1986, Bull. Seismol. Soc. Am. 76, 1830-1837.

Kohler, M. D. (1999). Lithospheric deformation beneath the San Gabriel Mountains in the southern California Transverse Ranges, J. Geophys. Res. 104, 15,025-15,041.

Kohler, M. D., and P. M. Davis (1997). Crustal thickness variations in southern California from Los Angeles Region Seismic Experiment passive phase teleseismic travel times, Bull. Seismol. Soc. Am. 87, 1330-1344.

Kohler, M. D., H. Magistrale, and R. W. Clayton (2003). Mantle heterogeneities and the SCEC Reference Three-Dimensional Seismic Velocity Model Version 3, Bull. Seismol. Soc. Am. 93, 757-774.

Langenheim, V. E. (1999). Gravity and aeromagnetic models along the Los Angeles Region Seismic Experiment (Line 1), California, U.S. Geol. Surv. Open-File Rept. 99-388, 22 pp.

Langenheim, V. E., and R. E. Powell (2009). Basin geometry and cumulative offsets in the Eastern Transverse Ranges, southern California: Implications for transrotational deformation along the San Andreas fault system, Geosphere 5, 1-22, doi 10.1130/GES00177.1.

Langenheim, V. E., R. C. Jachens, J. C. Matti, E. Hauksson, D. M. Morton, and A. Christensen (2005). Geophysical evidence for wedging in the San Gorgonio Pass structural knot, southern San Andreas fault zone, southern California, Bull. Geol. Soc. Am. 117, 1554-1572.

Lin, G., P. M. Shearer, and E. Hauksson (2007). Applying a threedimensional velocity model, waveform cross-correlation, and cluster analysis to locate southern California seismicity from 1981 to 2005 , J. Geophys. Res. 112, B12309, doi 10/1029/2007JB004986.

Lin, G., C. H. Thurber, H. Zhang, E. Hauksson, P. M. Shearer, F. Waldhauser, T. M. Brocher, and J. Hardebeck (2010). A California statewide three-dimensional seismic velocity model from both absolute and differential times, Bull. Seismol. Soc. Am. 100, 225-240, doi 10.1785/0120090028.

Magistrale, H., and C. Sanders (1996). Evidence from precise earthquake hypocenters for segmentation of the San Andreas fault in San Gorgonio Pass, J. Geophys. Res. 101, 3031-3044.

McGill, S., R. J. Weldon, and L. Owen (2008). Preliminary slip rates along the San Bernardino strand of the San Andreas fault, SCEC Annual Meeting 2008, abstract.

McKenzie, D. (1979). Finite deformation during fluid flow, Geophys. J. Roy. Astron. Soc. 58, 689-715.

Meisling, K. E., and R. J. Weldon (1989). Late Cenozoic tectonics of the northwestern San Bernardino Mountains, southern California, Bull. Geol. Soc. Am. 101, 106-128.

Nicholson, C. (1996). Seismic behavior of the southern San Andreas fault zone in the northern Coachella Valley, California: Comparison of the 1948 and 1986 earthquake sequences, Bull. Seismol. Soc. Am. 86, 1331-1349.

Nicholson, C., L. Seeber, P. Williams, and L. R. Sykes (1986). Seismicity and fault kinematics through the eastern Transverse Ranges, California: Block rotation, strike-slip faulting, and low-angle thrusts, J. Geophys. Res. 91, 4891-4908.

Nicholson, C., C. C. Sorlien, T. Atwater, J. C. Crowell, and B. P. Luyendyk (1994). Microplate capture, rotation of the western Transverse Ranges, and initiation of the San Andreas transform as a low-angle fault system, Geology 22, 491-495.

Perry, S., D. Cox, L. Jones, R. Bernknopf, J. Goltz, K. Hudnut, D. Mileti, D. Ponti, K. Porter, M. Reichle, H. Seligson, K. Shoaf, J. Treiman, and A. Wein (2008). The ShakeOut earthquake scenario-A story that southern Californians are writing, U.S. Geol. Surv., Circular 1324,16 pp.

Philibosian, B., T. E. Fumal, R. J. Weldon II, K. J. Kendrick, K. M. Scharer, S. P. Bemis, R. J. Burgette, and B. A. Wisely (2009). Photomosaics and logs of trenches on the San Andreas fault near Coachella, California, U.S. Geol. Surv. Open-File Rept. 2009-1039, 2 sheets (http://pubs.usgs .gov/of/2009/1039/).

Plafker, G. and J. P. Galloway (Editors) (1989). Lessons learned from the Loma Prieta, California, earthquake of October 17, 1989, U.S. Geol. Surv., Circular 1045, 48 pp.

Plesch, A., J. Shaw, C. Benson, W. Bryant, S. Carena, M. Cooke, J. Dolan, G. Fuis, E. Gath, L. Grant, E. Hauksson, T. Jordan, M. Kamerling, M. Legg, S. Lindvall, H. Magistrale, C. Nicholson, N. Niemi, M. Oskin, S. Perry, G. Planansky, T. Rockwell, P. Shearer, C. Sorlien, M. Sūss, J. Suppe, J. Treiman, and R. Yeats (2007). Community fault model (CFM) for southern California, Bull. Seismol. Soc. Am. 97, 1793-1802, doi 10.1785/0120050211.

Polet, J., and H. Kanamori (2002). Anisotropy beneath California: Shear wave splitting measurements using a dense broadband array, Geophys. J. Int. 149, 313-327.

Pysklywec, R. N., C. Beaumont, and P. Fullsack (2000). Modeling the behavior of the continental mantle lithosphere during plate convergence, Geology 28, 655-658.

Raikes, S. A. (1980). Regional variations in upper mantle structure beneath southern California, Geophys. J. Roy. Astron. Soc. 63, $187-216$.

Rogers, T. H. (1965). Geologic map of California, California Division of Mines and Geology, Sacramento, California, scale 1:250,000, Santa Ana sheet.

Rogers, T. H. (1967). Geologic map of California, California Division of Mines and Geology, Sacramento, California, scale 1:250,000, San Bernardino sheet.

Romanyuk, T., W. D. Mooney, and S. Detweiler (2007). Two lithospheric profiles across southern California derived from gravity and seismic data, J. Geodynam. 43, 274-307.

Rubin, A. M., D. Gillard, and J.-L. Got (1999). Streaks of microearthquakes along creeping faults, Nature 400, 635-641.

Ryberg, T., and G. S. Fuis (1998). The San Gabriel Mountains bright reflective zone: Possible evidence of young mid-crustal thrust faulting in southern California, Tectonophysics 286, 31-46. 
Schmandt, B., and E. Humphreys (2010). Seismic heterogeneity and small-scale convection in the southern California upper mantle, $G^{3}$ 11, no. 5, Q05004, doi 10.1029/2010GC003042.

Sharp, R. V., M. J. Rymer, and D. M. Morton (1986). Trace-fractures on the Banning fault created in association with the 1986 North Palm Springs earthquake, Bull. Seismol. Soc. Am. 76, 1838-1843.

Stewart, J. P., R. J. Archuleta, and M. S. Power (Editors), (2008). Earthquake Spectra 24, no. 1.

Tape, C., Q. Liu, A. Maggi, and J. Tromp (2010). Seismic tomography of the southern California crust based on spectral-element and adjoint methods, Geophys. J. Int. 180, 433-462, doi 10.1111/ j.1365-246X.2009.04429.x.

Waldhauser, F., and W. L. Ellsworth (2002). Fault structure and mechanics of the Hayward fault, California, from double-difference earthquake locations, J. Geophys. Res. 107, no. B3, doi 10.1029/2000JB000084.

Wilson, D. S., P. A. McCrory, and R. G. Stanley (2005). Implications of volcanism in coastal California for the Neogene deformation history of western North America, Tectonics 24, TC3008, doi 10.1029/ 2003 TC001621.

Wright, T. L. (1991). Structural geology and tectonic evolution of the Los Angeles basin, California, in Active Margin Basins, K. T. Biddle (Editor), Mem. Am. Assoc. Petrol. Geol. 52, 35-134.

Wooden, J. L., R. J. Fleck, J. C. Matti, R. E. Powell, and A. P. Barth (2001). Late Cretaceous intrusive migmatites of the Little San Bernardino Mountains, California, Abstr. Programs Geol. Soc. Am. 33, A65.

Wooden, J. L., R. M. Tosdal, K. A. Howard, R. E. Powell, J. C. Matti, and A. P. Barth (1994). Mesozoic intrusive history of parts of the eastern Transverse Ranges, California: Preliminary U-Pb zircon results, Abstr. Programs Geol. Soc. Am. 26, 104.

Yang, Y., and D. W. Forsyth (2006). Rayleigh wave phase velocities, small-scale convection, and azimuthal anisotropy beneath southern California, J. Geophys. Res. 111, B07306, doi 10.1029/ $2005 J B 004180$.

Yule, D., and K. Sieh (2003). Complexities of the San Andreas fault near San Gorgonio Pass: Implications for large earthquakes, J. Geophys. Res. 108, 2548, doi 10.1029/2001JB000451.

Zoback, M., S. Hickman, and W. Ellsworth (2010). Scientific drilling into the San Andreas fault zone, Eos Trans. AGU 91, 197-199.

\section{Appendix A}

Model of Combined Gravity and Magnetic Field Data in the Big Bend and Eastern San Gabriel Mountains

See Figure A1 and Figure A2.

\section{Appendix B}

\section{Dip of the SAF in the Big Bend Region, Evidence from Trenching}

At Smith Flat site (Davis, 1983; northwestern end of the Big Bend area), the main branch of the SAF, at the north end of the trench, dips approximately $65^{\circ}-70^{\circ}$ southwest, but a branch on the south end of the trench is steep. In Cuddy Valley trench (Davis, 1983; central part of the Big Bend area), the main branch, located in the central part of the trench, dips $55^{\circ}$ southwest, but adjacent branches dip $75^{\circ}-90^{\circ}$ southwest.

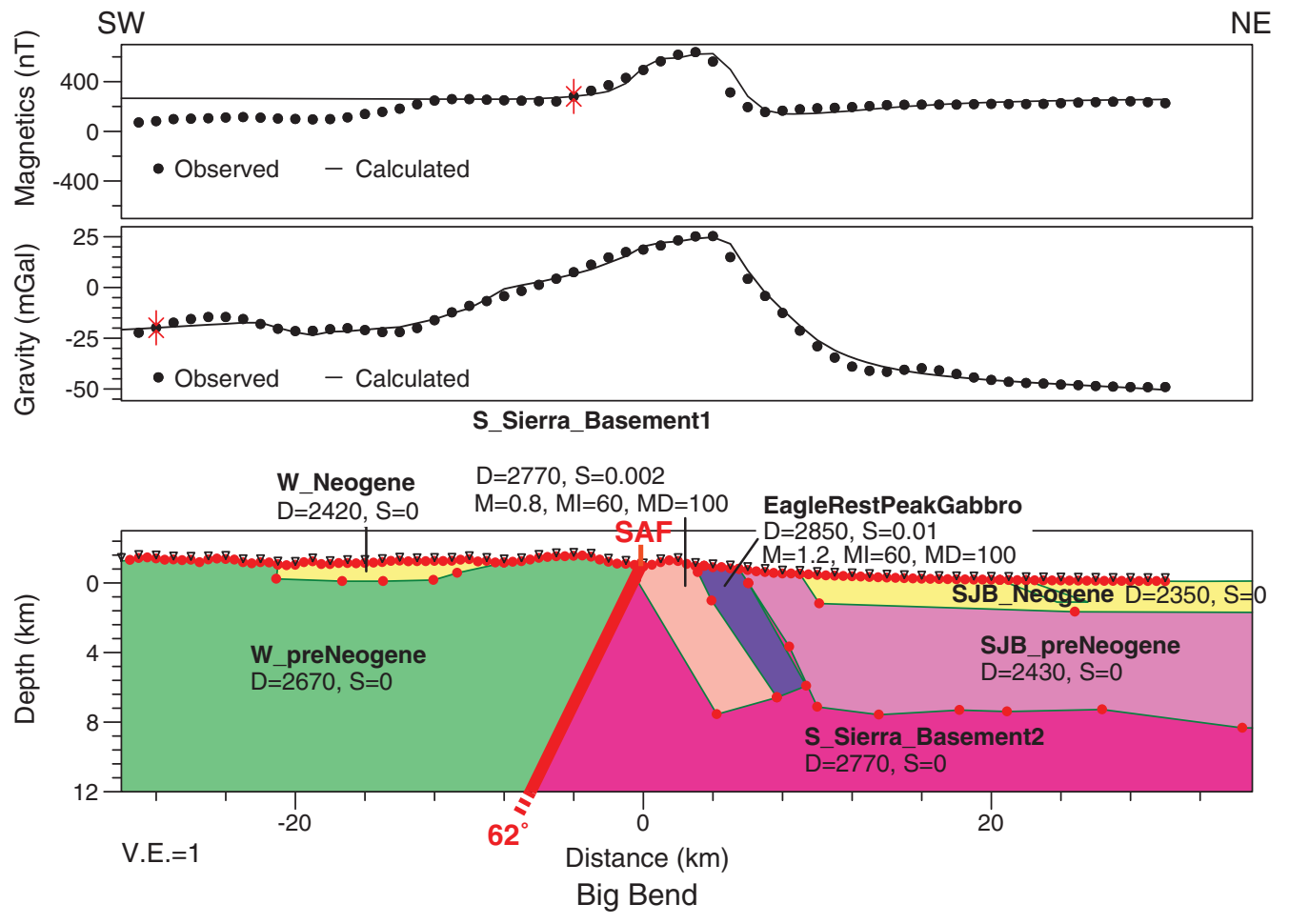

Figure A1. New model of combined gravity and magnetic field data along profile of Figure 3a, in Big Bend area of SAF. D, density $\left(\mathrm{kg} / \mathrm{m}^{3}\right) ; S$, magnetic susceptibility $\left(10^{-3} \mathrm{SI}\right) ; \mathrm{M}$, remnant magnetic intensity in $\mathrm{A} / \mathrm{m}$; MI, inclination of remnant magnetization vector; MD, declination of remnant magnetization vector. W_Neogene, Neogene sedimentary rocks west of the SAF; W_preNeogene, preNeogene, rocks west of the SAF; S_Sierra_basement 1, basement rocks of the southern Sierra block 1; S_Sierra_basement 2, basement rocks of the southern Sierra block 2; SJB_Neogene, Neogene sedimentary rocks of the San Joaquin basin; SJB_preNeogene, pre-Neogene rocks of the San Joaquin basin. Red stars are located where observed and calculated curves are constrained to agree. 

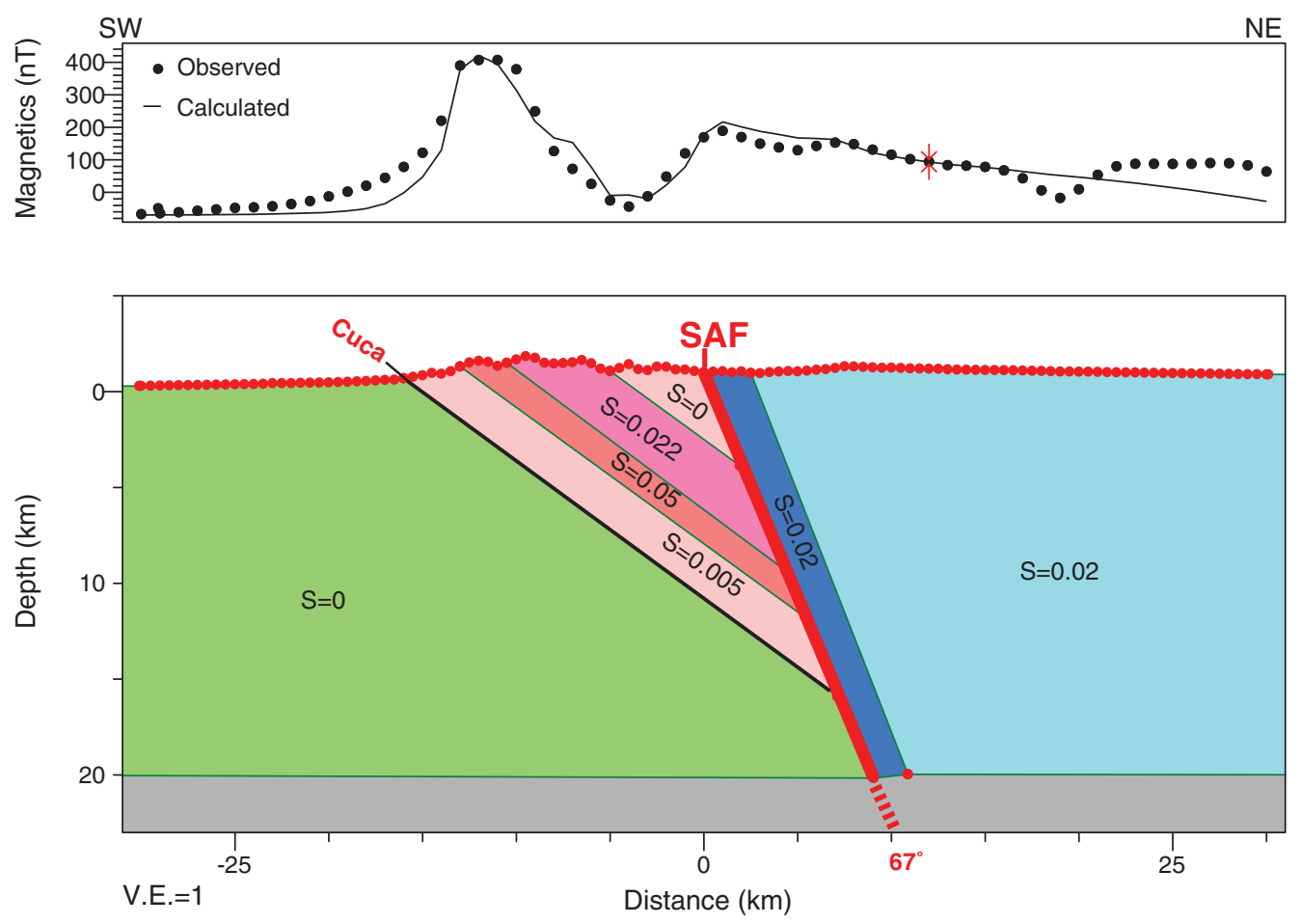

Eastern San Gabriel Mountains

Figure A2. Model of aeromagnetic data along seismicity profile of Figure 9b, through eastern San Gabriel Mountains. Cuca, Cucamonga thrust fault; S, magnetic susceptibility $\left(10^{-3} \mathrm{SI}\right)$. Red star is located where observed and calculated curves are constrained to agree.

A secondary fault at the south end of the trench dips $80^{\circ}$ northeast. The most modern trench, still under investigation by Kate Scharer, Thomas Fumal, Ray Weldon, and others (Thomas Fumal, written commun., 2009), at Frazier Park (near the junction of the SAF and Garlock fault), shows contradictory indications of dip. In the west wall of this trench, two primary breaks are seen that dip $55^{\circ}-85^{\circ}$ southwest. On the east wall of the same trench, the two main breaks are more diffuse, and, along with numerous minor breaks, appear to dip consistently $65^{\circ}$ northeast. It is probably significant that in cross sections extending to several kilometers depth in the Big Bend area, Davis (1983) defers to the preliminary gravity modeling results of Griscom and Oliver (1980; similar to the results of Griscom and Jachens, 1990) for the dip of the SAF (Figs. 1, 3a).

\section{Appendix C}

\section{Origin of the HVB}

Seismic properties of the HVB, including possible anisotropy, may be used to evaluate the hypothesis that the HVB represents oblique downwelling of the PAC along the plateboundary. The new tomographic models of Schmandt and Humphreys (2010) indicate that $P$ - and $S$-wave velocities are each increased in the HVB by $2-3 \%$ relative to a regional $1 \mathrm{D}$ velocity model of the southwestern United States, with the largest increase for the $S$-wave velocity. $V_{P} / V_{S}$ is correspondingly lower in the HVB. Explanations for these velocity perturbations are differences in temperature, partial melt fraction, composition (due to prior melt extraction), hydration, and transverse anisotropy. They favor differences in temperature $\left(<500{ }^{\circ} \mathrm{K}\right)$, partial melt $(<1 \%)$, and (or) transverse anisotropy.

There is some support for a density origin of the HVB from detailed 2D gravity and isostatic modeling by Romanyuk et al. (2007), although the gravity expression of this deep body is weak. Biasi (2009) has interpreted the origins of high-velocity mantle anomalies in California, concluding, based on volumetric arguments, that they do not have local sources (they are too big), but are possibly downwelled lithospheric roots of the Sierra Nevada and Peninsular Ranges batholiths. In particular, the HVB could be the downwelled root of the Peninsular Ranges batholith, although this interpretation is straightforward only for the eastern half of the HVB, where the Peninsular Ranges batholith is adjacent to the HVB on the south (Fig. 1).

The relatively low velocities of the upper-mantle of the Mojave Desert region, north of the HVB, may have originated from Cenozoic episodes of asthenospheric upwelling and volcanism. Humphreys (1995) has postulated that the flat segment of the Farallon slab subducted in the Laramide was removed by gravitational buckling (downwelling) along an east-west axis through southern Nevada and the southern Sierra Nevada, as evidenced by migration of volcanism toward this axis from both sides-northward through the southern Basin and Range/Mojave Desert region, southward 
(a)

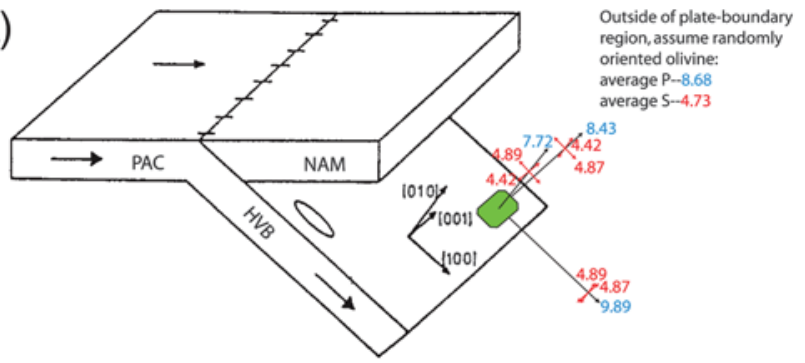

(b)

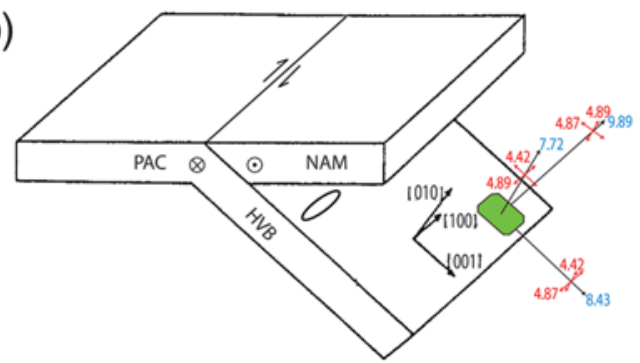

Figure C1. Alternate tectonic diagrams for HVB, showing different preferred orientations for olivine and seismic velocities (blue, $P$ wave; red, $S$ wave). (a) Diagram for subducting oceanic plate (adapted from McKenzie, 1979, his fig. 10b) that shows, with small ellipse, orientation of velocities for expected preferred orientation of olivine ( $a$-axis oriented down-dip) in mantle wedge immediately above slab (orientation results from shear). Note that in Transverse Ranges, slab (HVB) would be nearly vertical. Laboratory velocities for single-crystal olivine are shown (Babuska and Cara, 1991); average velocities for homogenized mantle outside of plate-boundary region are shown in upper right. In real mantle, velocity magnitudes would be modified from those in this diagram because (1) olivine is only statistically oriented as shown, (2) nonolivine crystalline phases are also present, and (3) mantle outside of plate-boundary region may well have preferred crystal orientations (may not be isotropic). This orientation of olivine correctly predicts observed relative velocity magnitudes of $P$ and $S$ waves separately, but not observed $V_{P} / V_{S}$ (see text). (b) This diagram assumes pure strike-slip between plates and assumes that olivine a-axis orientation (long axis of ellipse) is parallel to shear direction. This orientation of olivine does not give observed relative velocity magnitudes in many cases (see text).

through the Great Basin region. Asthenospheric upwelling associated with this slab removal presumably gave rise to increased heat flow, partial melt, and the observed volcanism. Subsequent events in the Mojave Desert include reestablishment of subduction west of the Mojave Desert region, followed by slab removal again in the wake of the subducted Mendocino fracture zone and associated volcanism (Wilson et al., 2005). Thus, at least two episodes of Cenozoic volcanism and inferred asthenospheric upwelling occurred in the Mojave Desert region; either or both may have contributed to the observed low upper-mantle velocities in this region.

On the south side of the HVB, middle and late Cenozoic extension of the crust and volcanism associated with the formation of the Los Angeles basin and inner Continental Borderland (Wright, 1991; Crouch and Suppe, 1993) may have also been associated with slab removal and upwelling asthenosphere (Nicholson et al., 1994; Wilson et al., 2005).
Thus, asthenospheric upwellings with somewhat different histories on either side of the HVB may account for the observed velocity differences. A final mechanism for achieving a contrast between the HVB and mantle on either side is simply local mantle upwellings on either side of a downwelling that is expected from mantle dynamics (see e.g., Houseman and Molnar, 1997; Houseman et al., 2000).

Anisotropy may be partly involved in the origin of the HVB. It is clear that uppermost-mantle compressional velocities $(P n)$ beneath southern California are anisotropic, with a west northwest fast direction (Hearn, 1984). This effect is not well resolved spatially, but could originate chiefly in the Transverse Ranges, which are central to the $P n$ study area of Hearn (1984). If the fast direction of mantle olivine grains ( $a$-axes) is oriented downward in steeply dipping shear zones in the mantle beneath the Transverse Ranges due to downwelling PAC, then: (1) the HVB would be apparent both from steeply inclined $P$ and $S$ imaging rays and from Rayleigh waves $(S v)$ (see images of Humphreys and Clayton, 1990; Yang and Forsyth, 2006; and Schmandt and Humphreys, 2010) ; (2) Pn anisotropy would be developed as observed (Hearn, 1984); and (3) SKS splitting would not change from outside to inside the footprint of the HVB, as is observed (e.g., Polet and Kanamori, 2002), because both vibration directions for steeply emergent $S$ waves would have the same speed in the model shown (Fig. C1a). This postulated orientation of olivine does not, however, explain the 1\%-2\% anisotropy modeled from Rayleigh-wave tomography (Yang and Forsyth, 2006). Significantly, however, $V_{P} / V_{S}$ for this orientation of olivine would be relatively high ( 2.0; Fig. C1a) rather than low as observed (Schmandt and Humphreys, 2010).

In contrast, Davis (2003) models the olivine $a$-axes in the HVB as pointing predominantly horizontally and northwest (Fig. C1b). This model would explain some of the previously discussed observations ( $P n$ anisotropy, neutral $V_{P} / V_{S}$ ) but not others (high relative $P$-wave and $S$-wave velocity of the HVB, no SKS change from outside to inside the HVB). Further studies, including detailed $P n$ tomography and forward modeling of various anisotropies will aid in determining the role of anisotropy in producing the HVB.

In summary, the HVB appears to be part of the PAC from our studies of the SAF in the crust and the geometry of the north side of the HVB. Interpretations of its origin as a downwelling of the PAC cannot be confirmed or dismissed at this time.

U.S. Geological Survey

Menlo Park, California 94025

(G.S.F., D.S.S., V.E.L.)

Center for Embedded Networked Sensing

University of California

Los Angeles, California 90095-1596

(M.D.K.)

Manuscript received 31 January 2011 